\title{
Technological change during final Mid-Holocene and early Late Holocene (ca. 5000-2000 years BP) in Barrancas (Jujuy province, Argentina)
}

\author{
Rodolphe Hoguin ${ }^{1,2}$, Patricio Kohan ${ }^{2}$ \\ 1. Consejo Nacional de Investigaciones Científicas y Técnicas (CONICET), Buenos Aires. Argentina. \\ Email: roddh2002@yahoo.fr \\ 2. Instituto de Arqueología (UBA, FFyL), Universidade de Buenos Aires, 25 de Mayo 221, 1002 Buenos Aires, \\ Argentina. Email: patriciokohan.91@gmail.com
}

\begin{abstract}
:
The archaeological evidence from the end of the Middle Holocene and the beginning of the Late Holocene ( $c a$. 5000-2000 years BP) shows a period of great changes. These appear to be the main result of low residential mobility occupations and subsistence strategies based in the specialized hunting of camelids, their domestication and further herding. Even though there is no consensus over the relative importance of each adopted strategy (hunting vs. herding) during this temporal sequence, several and relevant changes can be observed, related to many social spheres. In this paper, we present the particular changes over lithic technology during the temporal sequence proposed through two sites analysed from Barrancas: Laguna Media 7 and Morro Blanco. First, we will clarify the concept of technical system and describe the operative chains observed in both sites. This context is suitable for the topic addressed in this paper, since the chronological difference between both sites ( $c a$. 3400-3200 years BP) is almost contemporary with the appearance in the region of the domesticated camelid Lama glama. Thus, we explain the changes in lithic technology and their relation with the other raw materials used in different technologies from a qualitative characterization. Afterwards this change is characterized by performing separate Chi square analysis from the quantification between both sites of: transformative and prehensile techno-units, shaping and knapping methods. We detect some continuities related to the operative chains, but some changes as well, with the disappearance of blade knapping. Finally, we conclude that the changes during this time period are mainly related with the prehensile and hafting system, associated to a broader regional technological change, influenced by the circulation and exchange of goods, knowledge and people.
\end{abstract}

Keywords: lithic technology; Puna; Mid-Late Holocene; prehensile system; hafting system; innovations

\section{Introduction}

In Andean archaeology, the period between the end of the Mid-Holocene and the beginning of the Late-Holocene (ca. 5000-2000 ${ }^{14} \mathrm{C}$ years BP; 5500-2000 cal. BP), possesses

Published by the School of History, Classics and Archaeology, University of Edinburgh ISSN: 2055-0472. URL: http://journals.ed.ac.uk/lithicstudies/ 
numerous changes and technological innovations. Sites such as Caral or Tiahuanaco are two great examples to take into account, as they represent the beginning of the Andean civilizations (in terms of landscape urbanization) and the relevance of these changes. The Argentine Puna, was not an exception to these processes involving, among others, the sedentarization of human groups and the handling of domestic species -this representing one of the key aspects in the changes from the hunting-gathering strategies towards agro-pastoral ones- being contemporary or even older than in the northern part of this region (Yacobaccio 2001).

In this context, there were some important changes happening in the social, cultural and technological spheres. This dynamic contextualized the technological evolution, in particular, with the lithic instruments. The current paper presents the results of the lithic technology from two sites located in Barrancas (Province of Jujuy, Argentina): Laguna Media 7 and Morro Blanco (Figure 1), showing the processes occurred during the transition between the Middle and Late Holocene (ca. 3500-3000 ${ }^{14} \mathrm{C}$ years BP). Technological changes were discussed in the context of major ones in subsistence strategies, with hunting-gathering strategies no longer dominating (or at least, ceasing to be the only strategies used) with the rise of herding and agriculture in the highlands. As developed below, the lithic operating chains were related to other raw materials in several stages. This framework allowed us to understand technical changes occurred during this key-period in terms of cognitive, techno-economic and cultural aspects (Geneste 2010; Inizan et al. 1995; Lemonnier 1986) and from a "techno-logical" perspective (Boëda 2013).

\section{The concept of technical system}

The technical system is a conceptual tool initially formulated in anthropology to analyze techniques, how they function in human societies (Mauss 1950) and was later applied in archeology (Leroi-Gourhan 1971). This concept proposes ordering the different technical actions of the groups and their relationships. They are treated as interconnected subsystems in action, involving people, tools, gestures, raw materials, know-how and knowledge. Different variables are taken into account, such as cultural expressions, idiosyncrasies, restrictions, as well as economic, geographical and ecological aspects, among others. A given technical system works well in its environmental, cultural and social context (Geneste 2010; Lemonnier 1986; Leroi-Gourhan 1971). They usually involve different quality materials from different sources and therefore, several operating chains. Thus, lithic materials are privileged in archeology due to their durability, as it allows to rebuild almost completely their operational chains from the technical systems in which they operated (Geneste 2010; Inizan et al. 1995).

The operative chains (chaînes opératoires) consist of all the processes and stages, from the supply of raw materials to the abandonment, going through all the modifications and uses of the raw material. The use of this conceptual tool in archeology and anthropology is useful and adequate to distinguish between different degrees of events (degrés des faits). This means, to separate the cultural aspects (information transmission) from the economic ones or those more directly related to subsistence (Lemonnier 1986; Leroi-Gourhan 1971).

It is a greatly used tool in archeology, allowing to rebuild the knappers' objectives for the proper functionality of the lithic tools and their cultural aspects, the kind of raw materials used, their economy, and the knowledge and know-how involved (Geneste 2010; Inizan et al. 1995; Pelegrin 1995). The know-how (developed by practice) is an important concept to distinguish pragmatic and flexible decisions taken by knappers and its relation with the mental operating scheme (Boëda 2013; Pelegrin 1995). 


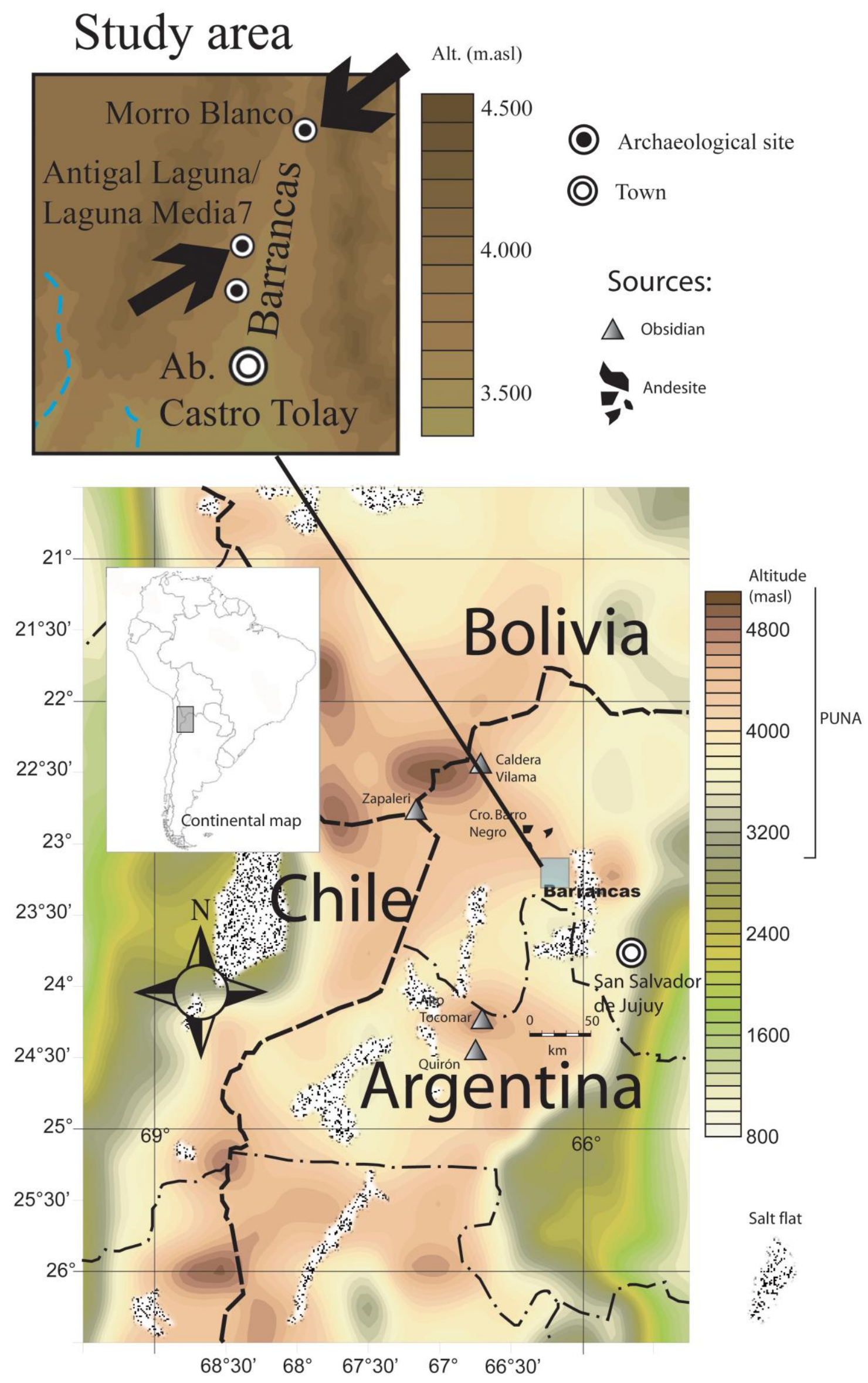

Figure 1. Localization map of archaeological sites. 
Likewise, these studies on a larger scale would allow us to distinguish the local or nonlocal innovations, inventions, and processes resulting from a logical evolution or a breakthrough in the technical lineages, which may be the product of profound changes in societies (Boëda 2013; Roux 2010).

\section{Palaeoenvironmental context and innovations in the South-Central Andes}

Before delving into technical systems and technology from the aforementioned geographical region, it is necessary to describe the known social and palaeoenvironmental context and framework, since, as previously stated, a contextual approach is necessary to properly interpret technical systems and lithic technology.

Palaeoenvironmentally speaking, in a regional scale, after the aridization process observed during the Mid- Holocene, an overall increase in humidity was noted in the Andean area records between 4500 and $2500{ }^{14} \mathrm{C}$ years BP. Subsequently, this period was followed by a decrease in humid conditions between 2500 and $1500{ }^{14} \mathrm{C}$ years BP, after which the current climate conditions settled. Locally, palaeoenvironmental studies showed a rather wet phase between ca. 4500 and $2000{ }^{14} \mathrm{C}$ years $\mathrm{BP}$, although it was interrupted by repeated dryness events (Pirola et al. 2018). These dryness events were represented in the PCC2 profile around $2100{ }^{14} \mathrm{C}$ years BP $\left(2100 \mathrm{cal}\right.$. BP) and $2400{ }^{14} \mathrm{C}$ years BP $(2500 \mathrm{cal}$. BP) (Morales et al. 2014), but also in other nearby locations, such as Pastos Chicos at $2900{ }^{14} \mathrm{C}$ years BP (3000 cal. BP) and $3070{ }^{14} \mathrm{C}$ years BP (3260 cal. BP) (Tchilinguirián et al. 2014). The different proxies (palaeomagnetism, diatoms, pollens, etc.) supported the existence of a relatively stable wetland and grassland (vega) in the region, though torrential events alternate regularly with the mentioned peaks of dryness (Pirola et al. 2018). More specifically, regarding the human impact on the landscape, the pollen studies in Barrancas suggested a remarkable anthropogenic change in the vegas after ca. $3600{ }^{14} \mathrm{C}$ years BP, probably related to the use of camelid herds (Oxman 2015).

The aforementioned period corresponds to the last fully hunter-gatherer occupation and the beginning of the first agro-pastoral occupation. Likewise, during the period covered in this paper, a great number of occupations were detected, and the study of the dates from these sites were consistent with a demographic growth (Muscio \& López 2017). The zooarchaeological studies showed evidence of an intensification and domestication process of camelids towards ca. $5000{ }^{14} \mathrm{C}$ years BP (Cartagena et al. 2007; López \& Orsi 2017; López \& Restifo 2014; Núñez et al. 2013; Yacobaccio 2001; 2012; among others). Towards the end of the mentioned period in this work, archaeofaunal studies made it possible to show a consolidation of herding practices, without abandoning hunting as a subsistence strategy (Escola 2000; 2002; López 2008; Yacobaccio et al. 1998). Intensification processes were also evident in the processing and consumption of plant resources towards the end of the Middle Holocene (Babot 2011).

These population dynamics and changes in subsistence strategies had a remarkable impact on the landscape, with the appearance of structures (in particular corrals used to handle herds in captivity) and the first human groups' congregation, in the end of the Middle Holocene in the Chilean slope (Núñez et al. 2006; 2013) and in the beginning of the Late Holocene in the Argentine slope (Muscio 2011; Olivera 2012). However, the first pastoral occupations did not underestimate the use of rock shelters (Aschero 2007; López 2008; López \& Orsi 2017; Yacobaccio et al. 2011). From ca. $2500{ }^{14} \mathrm{C}$ years BP, a period characterized in an integrated way by a productive economy, sedentary lifestyle and technological innovations began. The sedentary lifestyle in this case did not necessarily involve low mobility, as there might already be a high logistical mobility with residential bases agglutinated, stable enough and permanent in time, as well as other semi-permanent bases for isolated families, to access 
other resources (Olivera 2012). Over time, a greater concentration of the constructions, a hierarchy over spaces, and a size increase of the sites were observed (Delfino et al. 2007; Korstanje 2007; Olivera 2012).

Ceramics were one of the most characteristic innovations which marked the beginning of the Late Holocene. It is also relevant to mention the presence of isolated findings well before this date, as in PCh1.5, dated ca. 3800 years BP (Aschero \& Hocsman 2011), or in Ramadas in ca. 3600 years BP (Muscio 2011), but they have only begun to appear conspicuously in the archaeological contexts of the region from ca. $3200{ }^{14} \mathrm{C}$ years $\mathrm{BP}$ onwards. Likewise, metallurgy was another technological innovation which appeared ca. 2900 years BP (Angiorama \& Taboada 2008; Fernández Distel 1998; González 2004; among others). It is important to mention that these processes must have influenced greatly the social organization as well as the technological systems (in particular the lithic one) of the human groups who occupied the area of study between ca. $5000-2000{ }^{14} \mathrm{C}$ years BP.

In the Dry Puna ("Puna Seca" in Spanish), the aforementioned processes of intensification towards the end of the Middle Holocene (ca. 5500-4000 ${ }^{14} \mathrm{C}$ years BP) were related to the production and use of blades as blanks for tools (Hoguin 2014a; López \& Restifo 2012; Loyola et al. 2016; Núñez et al. 2006; Restifo 2015). This type of tool was accompanied by bifacial lanceolate projectile arrowheads associated with a spear-thrower system, which exceeded the geographical distribution of blades and its date of appearance ca. $6000{ }^{14} \mathrm{C}$ years BP in its early phase, disappearing around ca. $2000{ }^{14} \mathrm{C}$ years BP in its late phase (Aschero et al. 2011; Hoguin 2014b; Lavallée et al. 1995; Núñez et al. 2006; de Souza et al. 2010; Yacobaccio et al. 2011). Only then, during the late Holocene (ca. $3000{ }^{14} \mathrm{C}$ years BP), small triangular arrowheads with barbed shoulders and stems appeared, mostly associated with the bow and arrow propulsion system in different areas of the Salt and Dry Puna (Escola 2002; Fernández Distel 1998; Mercuri 2014). Towards the end of this temporal sequence, the provenance studies of the obsidians allowed to demonstrate the existence of a distribution sphere whose main source was Zapaleri in the northern zone of the Argentine Puna (Yacobaccio et al. 2004). This sphere would have been active for the Barrancas basin, as shown by the XRF studies on obsidian from Morro Blanco and Laguna Media 7 (Yacobaccio et al. 2017), as well as being related to caravan traffic. Indeed, the access to certain resources from other ecological levels, and the circulation of goods, knowledge and people, were secured by llama caravans in a regular exchange system, even though, it was not very intense (Yacobaccio 2012).

\section{Presentation of the sites}

\subsection{Antigal Laguna and Laguna Media 7}

West from the Barrancas River, there is a large terrace associated with several small rock shelters, mounds (Figure 2) and housing structures. The mounds are artificial structures, mostly made from local quartzites and ignimbrite, but we still do not know their exact functionality. They are associated with part of the lithic material here presented (Table 1). Several test pits were carried out in the rock shelters and on the slope, as well as inside and outside the housing structures, in which bone and lithic materials were found, including ceramics and glass beads in the Antigal. Only in the lower sector of the site (in the Antigal part) were ceramics found on the surface. The date obtained $\left(220 \pm 30{ }^{14} \mathrm{C}\right.$ years $\mathrm{BP}$, Gif\#A17281) from a charcoal coming from the ash lenses (layer 2) matched the dates of the occupation from layer 1 (Colonial Period). In the third test pit from the rock shelter, two layers were also found, but with a much lower sedimentation rate. One burned bone was dated, and it appeared to belong to the transition between the Middle and Late Holocene (Figure 2). As the lithic material (apparently with a late Middle Holocene chronology due to 
the presence of blades and Saladillo related tools), appears in all the sectors previously mentioned, an extensive occupation from the late Middle Holocene could have occupied the entire area.

It was thus possible to distinguish two main occupations, an older one from the Middle Holocene -extending towards the late Holocene by the radiocarbon date obtained (Table 2)-, and a more recent one from the historical period (although the architectural and ceramic traits appear from the Inca period).
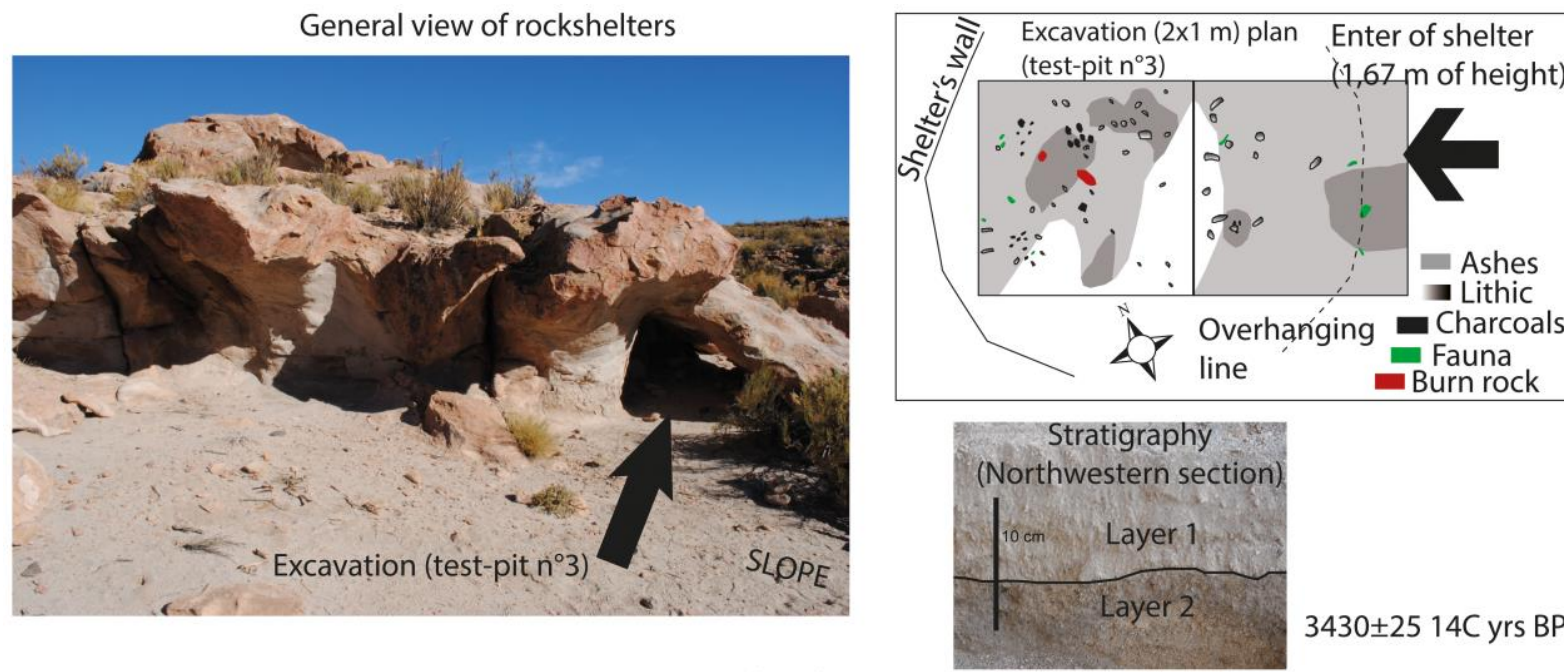

$3430 \pm 2514 C$ yrs BP

Plan of artificial mounds

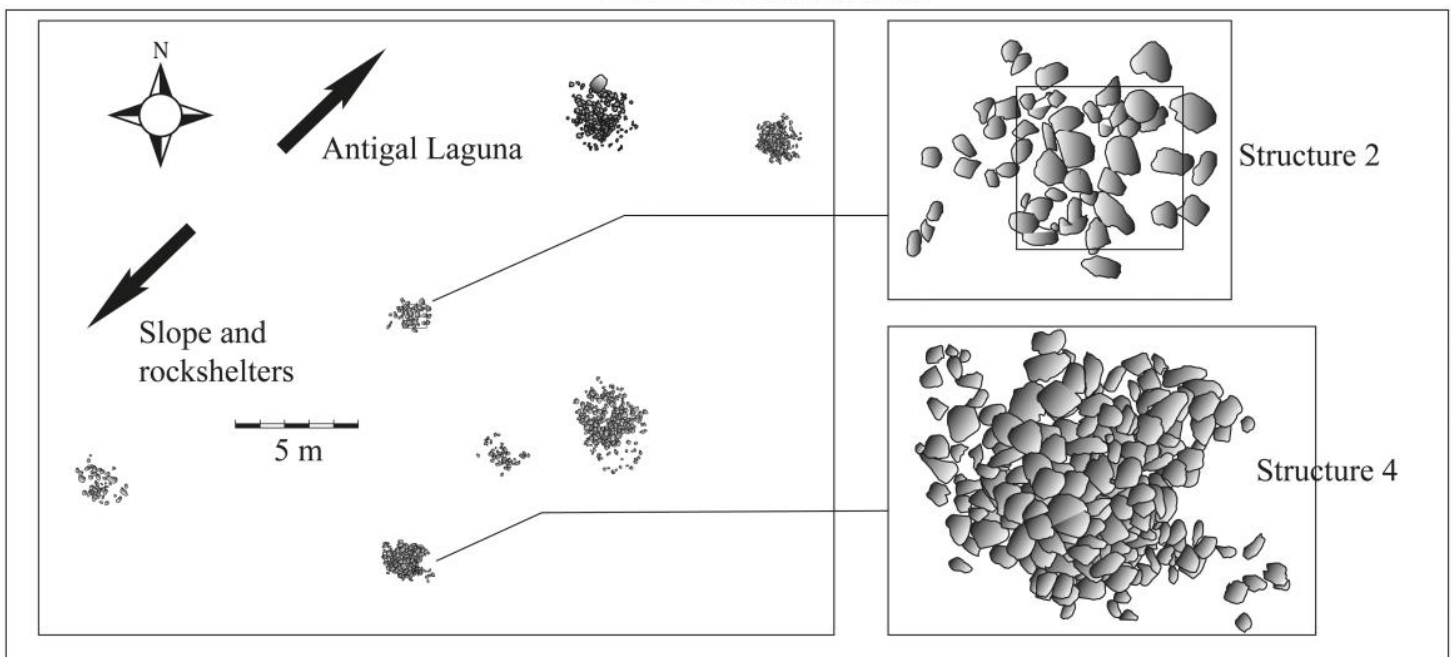

Figure 2. Laguna Media 7. General view of rock shelter, Excavation plan, stratigraphic column and artificial mounds sector map.

\subsection{Morro Blanco}

In this site, it was possible to distinguish two main sectors: the rock shelter with its drip line, and a terrace bounded by a fallen block and two badlands (Figure 3). Several panels of engravings and painted rock art are associated with the site. Six dates (three in each sector) were made on charcoals for each level and extraction, allowing to date the site to the beginning of the late Holocene (Figure 3). A great variety of materials were found: bones, lithics (Table 3), vegetables, animal leather and fibres, shell beads, and ceramic sherds, whose characteristics (such as stemmed and barbed shoulders arrowheads, bifacial lanceolate arrowheads and Los Morros ceramic) are coherent with the dates, suggesting a continuous occupation overall, except the latest one (Table 2). 
Table 1. Lithic materials of Laguna Media 7 classified following raw material and chaîne opératoire by-products.

\begin{tabular}{|c|c|c|c|c|c|c|c|c|c|c|c|}
\hline & \multirow[b]{2}{*}{ Materials } & \multicolumn{3}{|c|}{ Knapping } & \multicolumn{5}{|c|}{ Tools } & \multirow[b]{2}{*}{ Total } & \multirow[b]{2}{*}{$\%$} \\
\hline & & Cores & Cortical & Flakes & Confection & Retouched & Shaped & Others & Ind. & & \\
\hline \multirow[t]{4}{*}{ Local } & Quartzite & 24 & 1 & 318 & 798 & 70 & 97 & 2 & 10 & 1320 & 85 \\
\hline & Opal & 0 & 0 & 2 & 11 & 1 & 0 & 0 & 0 & 14 & 1 \\
\hline & Quartz & 2 & 0 & 0 & 5 & 0 & 0 & 0 & 0 & 7 & 0.5 \\
\hline & Quartzite v2 & 0 & 0 & 2 & 7 & 1 & 1 & 0 & 0 & 11 & 1 \\
\hline \multirow[t]{5}{*}{ Non-local } & Andesite & 3 & 0 & 57 & 54 & 20 & 25 & 0 & 5 & 164 & 11 \\
\hline & Obsidian & 0 & 0 & 2 & 25 & 0 & 1 & 0 & 0 & 28 & 2 \\
\hline & Others & 0 & 0 & 0 & 2 & 0 & 0 & 0 & 0 & 2 & 0.1 \\
\hline & Total & 29 & 1 & 381 & 902 & 92 & 124 & 2 & 15 & 1546 & \\
\hline & $\%$ & 2 & 0.1 & 25 & 58 & 6 & 8 & 0.1 & 1 & & \\
\hline
\end{tabular}

Table 2. Radiocarbon dating from both sites (Morro Blanco dates taken from Yacobaccio et al. 2018)

\begin{tabular}{|c|c|c|c|c|c|c|c|}
\hline Site & Localisation & Layer & Dates (14C years BP) & Calibrated dates ( $2 \sigma$ range) & Method & Material & Laboratory code \\
\hline Laguna Media 7 & Test-pit $n^{\circ} 3$ & 2 & $3430 \pm 25$ & $3562-3703$ & AMS & Bone & GifA\#17286 \\
\hline \multirow[t]{5}{*}{ Morro Blanco } & C1 (Shelter B) & $1\left(2^{\circ}\right)$ & $3190 \pm 80$ & $3159-3567$ & $14 \mathrm{C}$ & Charcoal & LP-3299 \\
\hline & C1 (Shelter B) & 2 & $3075 \pm 25$ & $3144-3349$ & AMS & Charcoal & GifA\#17283 \\
\hline & C1 (Shelter B) & $1\left(1^{\circ}\right)$ & $2830 \pm 70$ & $2781-3083$ & $14 C$ & Charcoal & LP-3296 \\
\hline & Terrace A & 1 & $2255 \pm 25$ & $2676-2742$ & AMS & Bone & GifA\#16252 \\
\hline & Terrace A & 1 & $2560 \pm 20$ & $2489-2644$ & AMS & Charcoal & GifA\#17284 \\
\hline
\end{tabular}




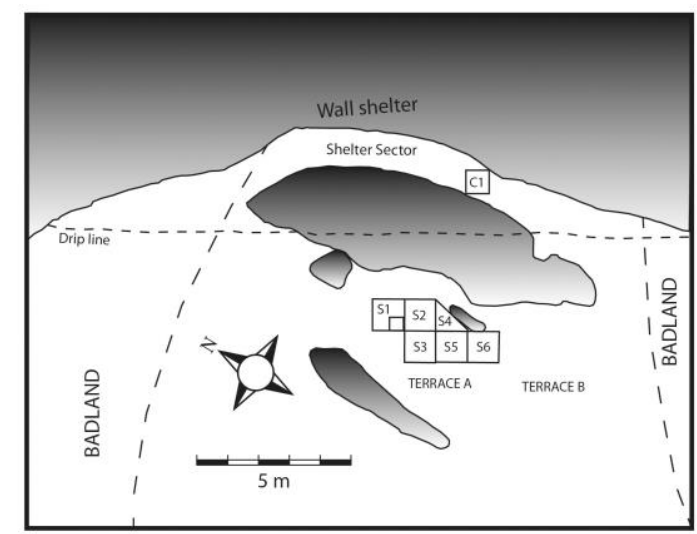

General plan of site
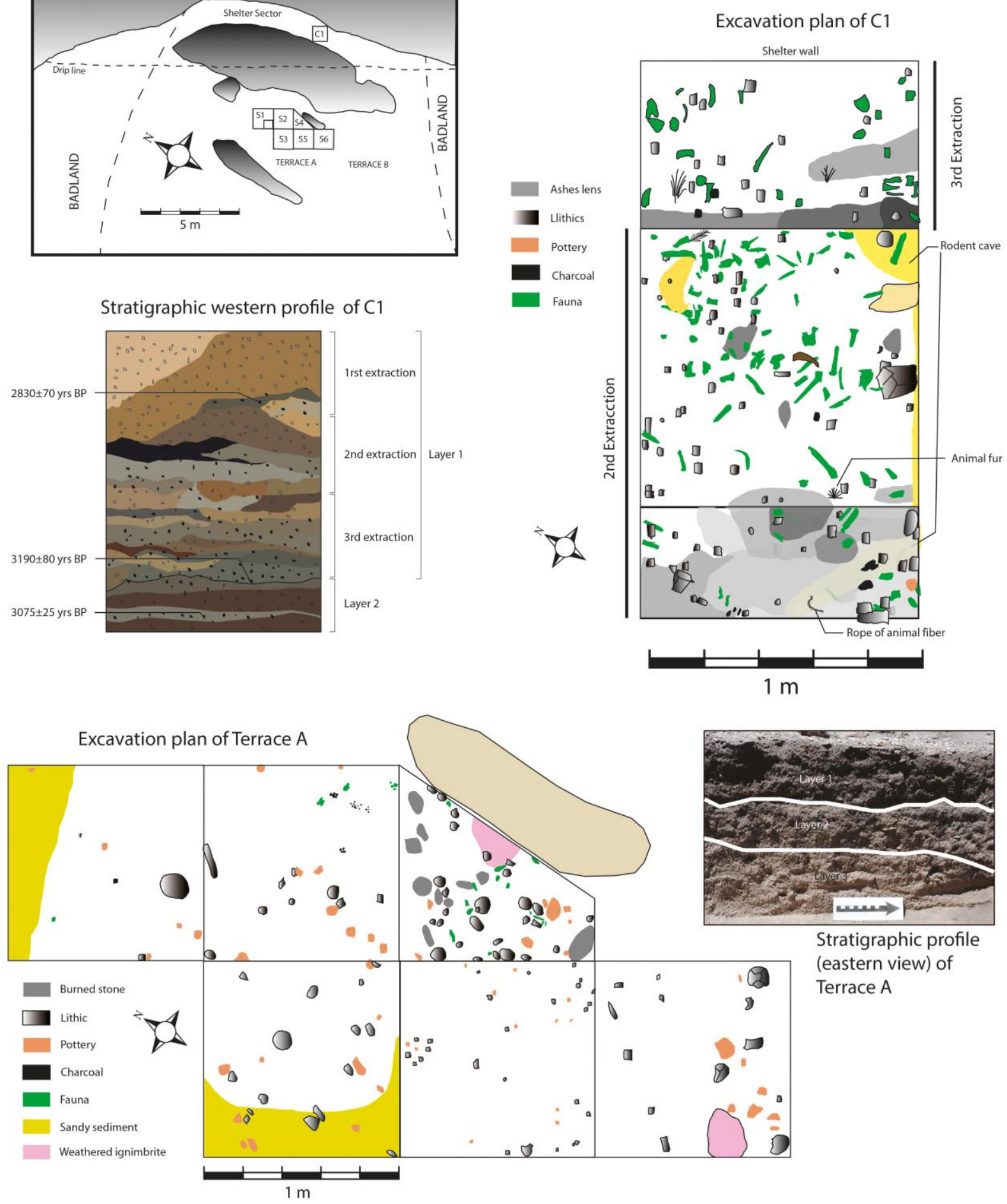

Figure 3. Morro Blanco. General view of rock shelter. Excavation plans and stratigraphic columns.

This chronological continuity, as much in the site as in comparison with Laguna Media 7 , may be suitable for the study of technological change. For the purpose of this work, technological analysis was carried out separately by site. The methodological decision to study the sites separately was given by the context: the presence or the absence of certain diagnostic materials revealing a marked change, such as ceramics, blades and stemmed projectile points with barbed shoulders. 
Table 3. Lithic materials of Morro Blanco classified following raw material and chaîne opératoire by-products.

\begin{tabular}{llcccccccccc}
\hline & \multicolumn{1}{c}{} & \multicolumn{1}{c}{ Knapping } & \multicolumn{1}{c}{ Tools } & \multicolumn{1}{c}{} \\
& Material & Cores & Cortical & Flakes & Confection & Retouched & Shaped & Others & Ind. & Total & \% \\
\hline \multirow{2}{*}{ Local } & Quartzite & 13 & 22 & 177 & 124 & 34 & 6 & 0 & 0 & 376 & 51 \\
& Opal & 3 & 0 & 5 & 27 & 1 & 0 & 2 & 3 & 41 & 6 \\
& Quartz & 3 & 8 & 48 & 65 & 4 & 3 & 19 & 22 & 172 & 23 \\
& Quartzite v2 & 0 & 0 & 0 & 1 & 0 & 1 & 0 & 0 & 2 & 0,3 \\
\hline \multirow{2}{*}{ Non-local } & Andesite & 0 & 0 & 2 & 16 & 1 & 3 & 0 & 0 & 22 & 3 \\
& Obsidian & 1 & 0 & 3 & 103 & 7 & 4 & 2 & 0 & 120 & 16 \\
\hline & Others & 0 & 0 & 0 & 3 & 0 & 0 & 0 & 0 & 3 & 0,4 \\
\hline & Total & $\mathbf{2 0}$ & $\mathbf{3 0}$ & $\mathbf{2 3 5}$ & $\mathbf{3 3 9}$ & $\mathbf{4 7}$ & $\mathbf{1 7}$ & $\mathbf{2 3}$ & $\mathbf{2 5}$ & $\mathbf{7 3 6}$ & \\
& $\%$ & 3 & 4 & 32 & 46 & 6 & 2 & 3 & 3 & & \\
\hline
\end{tabular}




\section{Materials and methods}

From the pit tests and excavations previously presented, 1546 artefacts were collected and analyzed from Laguna Media 7 (955 from the excavations and 591 from the surface) and 736 in Morro Blanco (554 from the excavation and 182 from the surface). For the aforementioned reasons, the analysis was performed by separating the sites from each other.

The techno-functional units (TFU) of the tools were identified (Boëda 2013). These were divided into two large classes: transformative $\left(\mathrm{TFU}_{\mathrm{t}}\right)$ and prehensile $\left(\mathrm{TFU}_{\mathrm{p}}\right)$. The technofunctional units answer to certain criteria that the instruments have in order to be functional in action (accompanied by a gesture), and obtained by knapping and retouching or by shaping, answering to a certain objective the knapper has (Boëda 2013). They were then identified from the morphological features in the plan and section of the artefact, as well as from its technological aspects, that is to say, by the study of the organization of the scars and removals on the tool. Then these traits are studied in relation to each other to determine which is transformative and which is prehensile or hafted.

The lithic operational chains were reconstituted by physical and mental (Geneste 2010; Pelegrin 1995) refittings. The latter were carried through the classification of the different artefactual classes: cores, initialization flakes, knapping flakes, confection flakes, blanks and tools. For each type of artefact the removals, their direction and the position of the negative bulbs were identified. In this way, illustrations were made following the codings of Inizan et al. (1995). An analytical cut was made between knapping and façonnage (shaping). The first consists of knapping a block to remove a flake consisting of the blank sought by the knapper to be the support of a tool. A subsequent confection (façonnage or retouching) is possible in order to give the tool its final functionality and eventually customize it from a cultural point of view (an event that can also occur during the knapping). On the contrary, the shaping (façonnage) consists of formatting a block or a blank that consists of the matrix sought to make the tool (Inizan et al. 1995). In this way the removed flakes are not the desired products, although they can function later as blank for tools. It is important to estimate the importance of knapping and shaping in the artefacts' functional criteria for the study of change and technical evolution (Boëda 2013).

Sketches were also made from the operational chains of knapping and classified according to their degree of integration. This consists of defining how much volume is integrated into artefactual production relatively with the remaining volume (Boëda 2013). Thus, different types were defined, of which 3 (C, D and E) were identified in this work. The first two were considered "additional" structures. This means that the different surfaces, platforms and faces of the knapping process were independent from each other. The last one (type E) is an "integrated" structure, and in this case, all the surfaces had a role and a dependence to carry out the knapping. More specifically, Type $\mathrm{C}$ was a volume selected due to its convexities and natural angles that would allow the removal of a predetermined blank; in the case of a Type D, the surfaces (platform and surface of the knapping) must have been prepared, which would allow to obtain another series from the same surfaces. Finally, Type E was knapped to obtain blanks in a systematized and recurrent manner, requiring a close relationship between its worked surfaces. Examples of this were the pyramidal (blades) and discoidal cores (Boëda 2013).

Separately by site, the cores and blanks (unmodified and tools) were quantified by the aforementioned classes, identifying the method and the degree of integration. For each instrument, the shaping was characterized by two main variables: the position (bifacial, unifacial, alternate methods) and extension (partially extended, invasive, and covering). From this perspective, retouching is always marginal and its use corresponds to a slight modification because the blank was obtained in order to already have the TFU. The TFUt 
(burin, sinuous edges, denticulate, side-scraper, knife, scraper, rostrum, perforators, arrowheads and notches) and the TFUp (peduncle, notch, back obtained by knapping, back obtained by shaping, natural, sinuous edge and thinning) of the tools and blanks were quantified by the whole assemblage.

In all the analyses, the undetermined classes were not taken into account in statistical analysis, thus avoiding noises on diversity interpretation. Likewise, only knapped (that is to say knapped and shaped) materials were analyzed here. This present work did not take into account polished, grounded and percussion classes.

Finally, the data analysis was then presented according to the following categories: transformative TFU, prehensile TFU, knapping method and shaping. For each particular case, the $\mathrm{x}^{2}$ test was used to compare the distributions between the two sites in order to test the null hypothesis of no correlation between the different levels of the categorical variables. When faced with frequencies less than 5 , as observed for some of the registered characteristics (especially regarding prehensile TFU) the probability associated with the $\mathrm{x}^{2}$ test was estimated by the Monte Carlo approximation ( $n=9999$ permutations), which provides a more precise and conservative context.

\section{Results}

\subsection{The transformative techno functional units}

Over ten classes of $\mathrm{TFU}_{\mathrm{t}}$ were identified: burin, sinuous edges, denticulate, side-scraper, knife, scraper, rostrum, perforators, arrowheads and notches.

The transformative TFU representing projectile points were identified in both sites, but more specifically in Morro Blanco. They are mostly made from immediately local quartzite in Laguna Media 7 (67\%) and a diversity of rocks in Morro Blanco (non-local obsidian, local fine-grained quartzite, quartz, and intermediate andesite). The burins also show an interesting relation between Laguna Media 7 and Morro Blanco, where they are better represented. While in the latter, they are associated with rock art engravings, showing traces of being used against hard materials (such as the ignimbrite in which said engravings were made), in Laguna Media 7 there was a complete absence of engravings or any form of rock art. These artefacts are mostly manufactured in quartzite $(91 \%)$. The size as well as use wear traces seem to show that while the burins in Morro Blanco were mainly used to perform activities over hard materials, in Laguna Media 7, they were related to processing animal or vegetable resources.

The different distribution observed between both sites (Figure 4) in activities does not mean that functional activities were different because of a technological change through time, but could be linked with the spatial location of sites and their specific activities.

Comparing the transformative TFU from both sites, the result of $\mathrm{x}^{2}$ was significant (Table 4), rejecting the null hypothesis of similarity in the distributions $\left(x^{2}, p<0,001 p=1,94 \mathrm{E}-\right.$ 07), which was also consistent with the approximation of Monte Carlo $(p=0,0001)$. The normalized residuals also suggest that burins and projectile points were the categories with the greatest weight in the samples. The weight of the notches and the knives was equally remarkable in the sample (Table 4). These classes reflected the greatest difference in activities between both sites. 


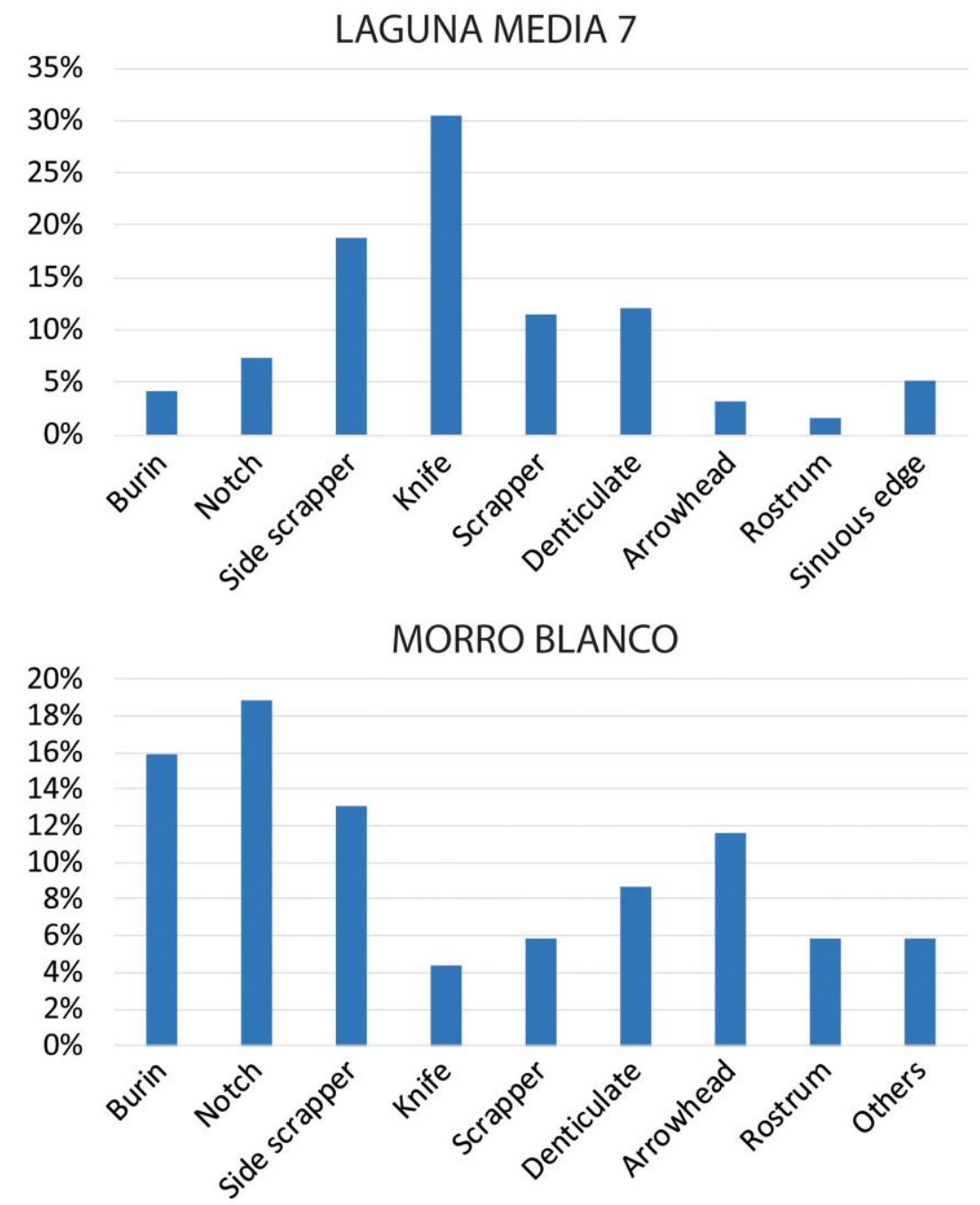

Figure 4. Distribution (percentages) of $\mathrm{TFU}_{\mathrm{t}}$ on Laguna Media 7 and Morro Blanco.

Table 4. Frequencies and normalized residuals for the Transformative TFU from Laguna Media 7 and Morro Blanco $-\mathrm{x}^{2}$ and Monte Carlo results.

\begin{tabular}{lcccc}
\hline & \multicolumn{2}{c}{ Frequency } & \multicolumn{2}{c}{ Residuals } \\
TFUt & Laguna Media 7 & Morro Blanco & Laguna Media 7 & Morro Blanco \\
\hline Burin & 8 & 11 & -6.2697 & 6.2697 \\
Notches & 14 & 13 & -6.278 & 6.278 \\
Side-scrapers & 36 & 9 & 2.2033 & -2.2033 \\
Knives & 58 & 3 & 12.187 & -12.187 \\
Scrapers & 22 & 2 & 3.9751 & -3.9751 \\
Denticulate & 23 & 6 & 1.2199 & -1.2199 \\
Arrowhead & 6 & 8 & -4.5145 & 4.5145 \\
Rostrum & 3 & 4 & -2.2573 & 2.2573 \\
Perforator & 1 & 1 & -0.50207 & 0.50207 \\
Sinuous edge & 10 & 3 & 0.23651 & -0.23651 \\
\hline Total & 181 & 60 & & \\
\hline Chi squared & \multicolumn{5}{l}{} \\
\hline Rows, columns: & 10,2 & \multicolumn{5}{l}{ Degrees freedom: } \\
x2: & 48.641 & p (no assoc.): & $1.94 \mathrm{E}-07$ \\
\hline Monte Carlo $\mathrm{p}:$ & 0.0001 & \multicolumn{5}{l}{} \\
\hline
\end{tabular}




\subsection{The prehensile techno functional units}

Six large classes of prehensile techno-functional units $\left(\mathrm{TFU}_{\mathrm{p}}\right)$ were identified: notches, peduncle, back (obtained by extended or partially extended retouching), back (already present from the blank), sinuous edge, and thinning (proximal). These $\mathrm{TFU}_{\mathrm{p}}$ involved different ways of prehension: axial hafting for the peduncles and the bulb thinning of the proximal parts (Figure 5: 1 to 6, Figure 6: 11 to 19), lateral manual or axial-lateral grasping for the backs (either shaped or previously present in the blank) and sinuous edges (Figure 5: 7 to 10; Figure 7: 20 to 22, 24), oblique or lateral hafting for notches (Figure 7: 23). The presence of two simultaneous $\mathrm{TFU}_{\mathrm{p}}$ such as proximal thinning and back was remarkable, as observed with tools of the Saladillo technical tradition (Figure 5: 2). These artefacts $(\mathrm{N}=32$ ) are mostly made of quartzite $(78 \%)$ and andesite $(22 \%)$.

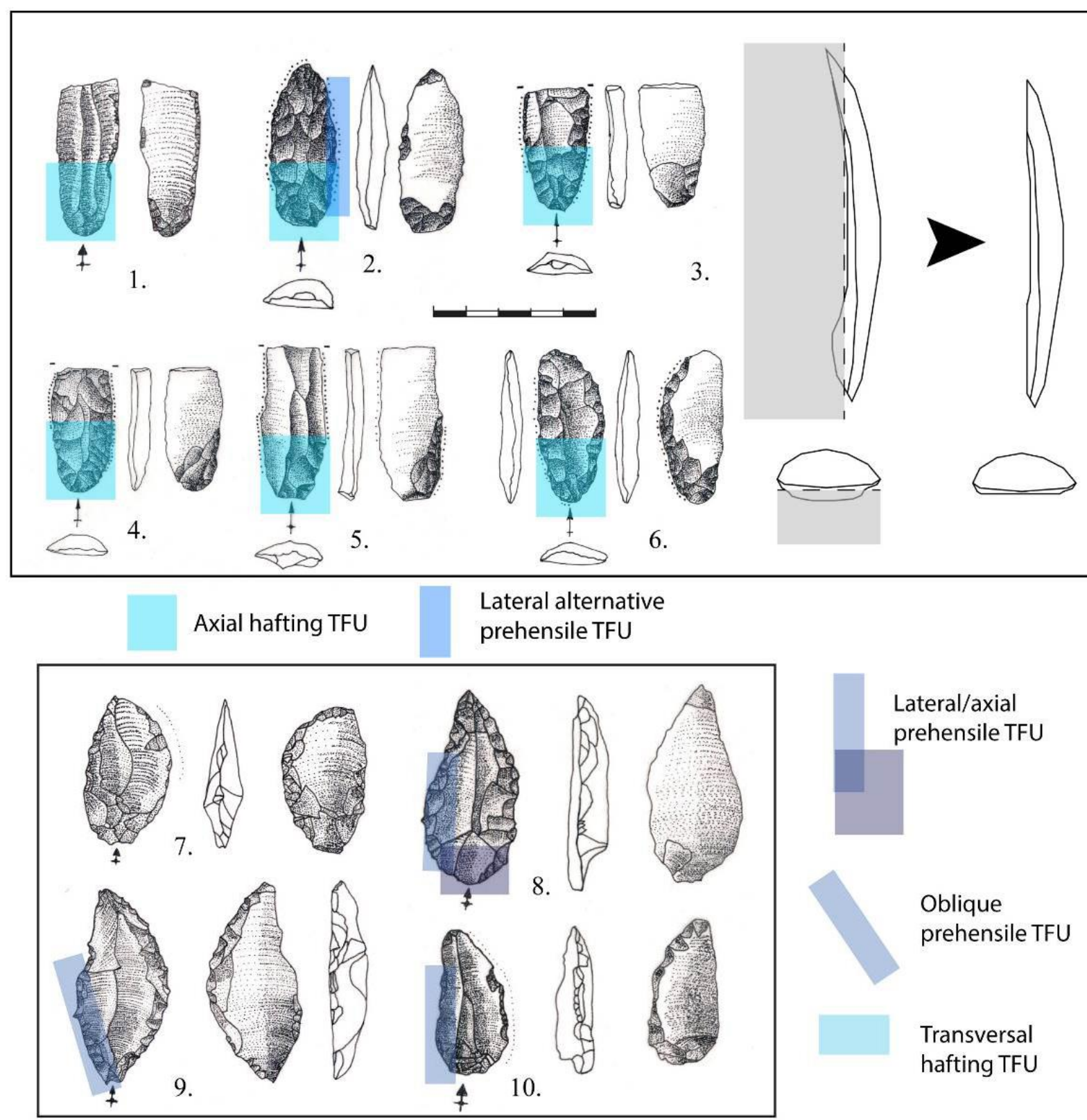

Figure 5. Different tool classes and their prehensile modes in Laguna Media 7. 


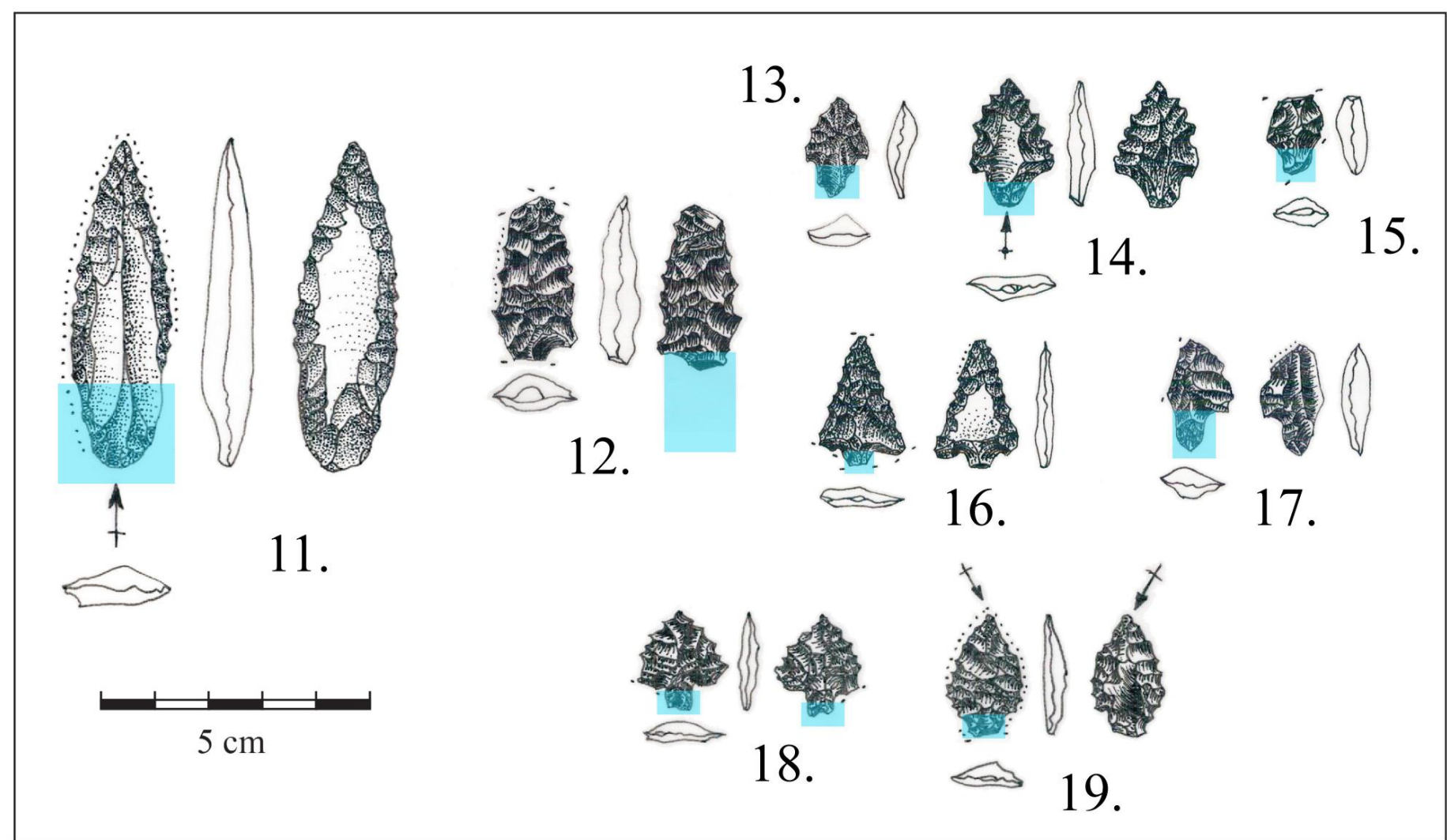

Figure 6. Arrowhead and their prehensile modes in Morro Blanco. 

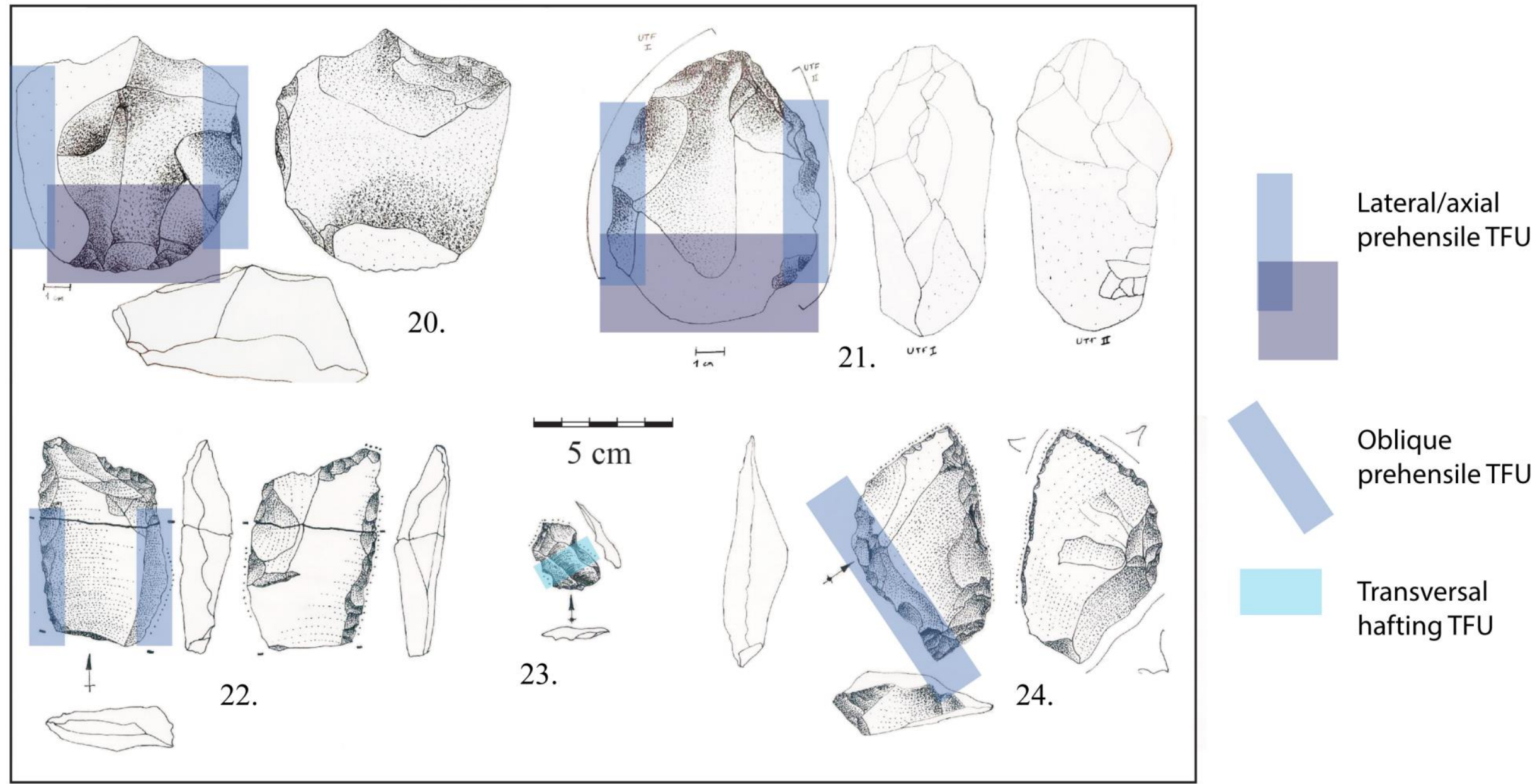

Figure 7. Different tools and their prehensile modes in Morro Blanco. 
Similar tendencies were highlighted in terms of the hafting axis and the axial or lateral prehension between both sites, with a stronger tendency towards the axial handling in Morro Blanco (Figure 8). The thinning of the proximal parts was a $\mathrm{TFU}_{\mathrm{p}}$ dominant trait in Laguna Media 7 while in Morro Blanco the peduncles dominated (Figure 8). Although it was low, the exclusive presence of the shaped backs was notable in Laguna Media 7. The sinuous edges and the back (knapping) were more used as TFUp in Morro Blanco than in Laguna Media 7 (Figure 8).

In the case of the Prehensile TFU, the results should be taken with certain precaution, even though the results (as in this case) were significant (Table 5). In effect, the null hypothesis of association between the two distributions was rejected $\left(x^{2}, p<0.001\right)$. The normalized residuals suggested that the frequencies of peduncles in Morro Blanco and bulb thinning in Laguna Media 7 showed the greatest differences between the observed and expected frequencies between both sites.
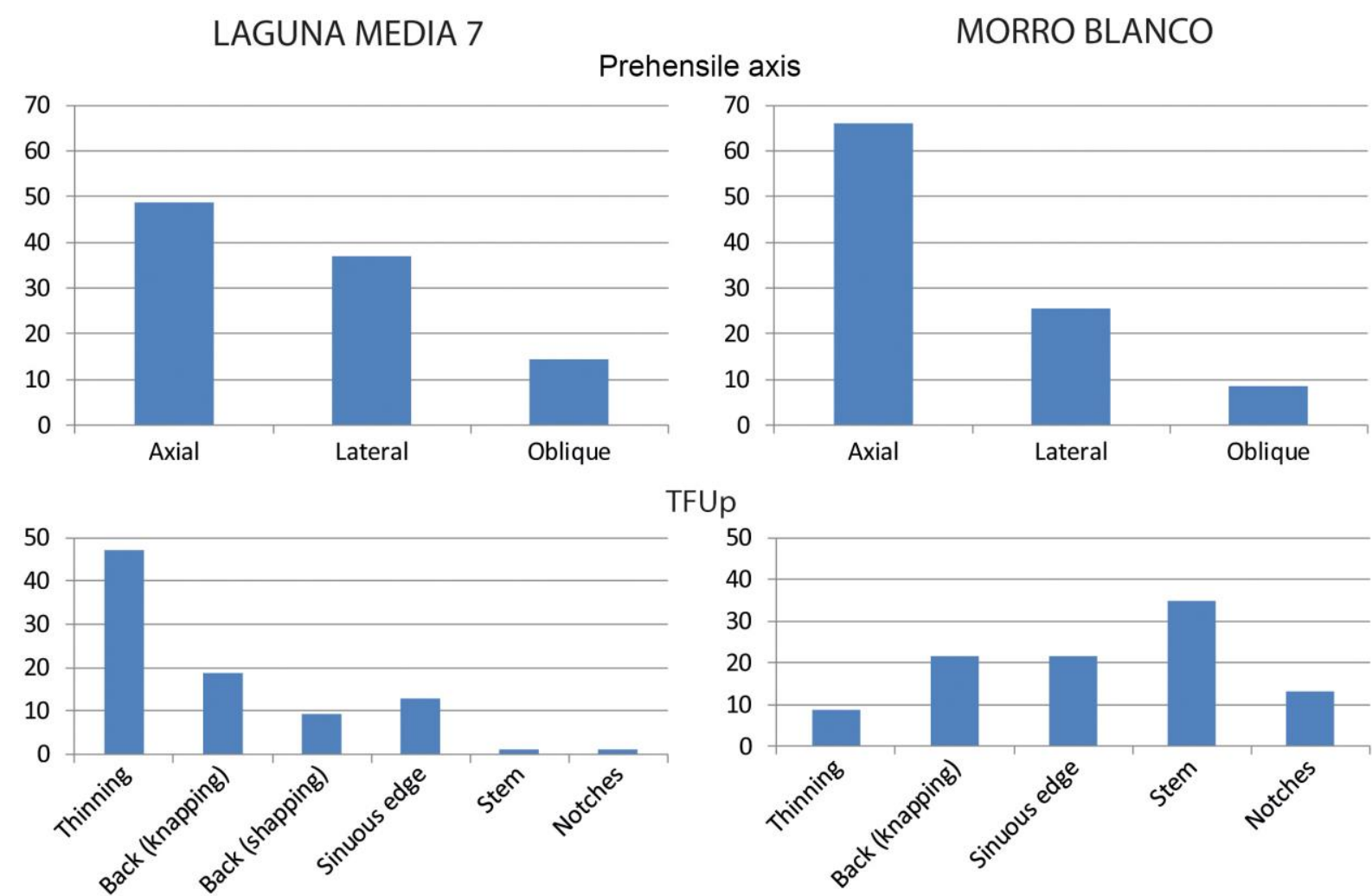

Prehension type
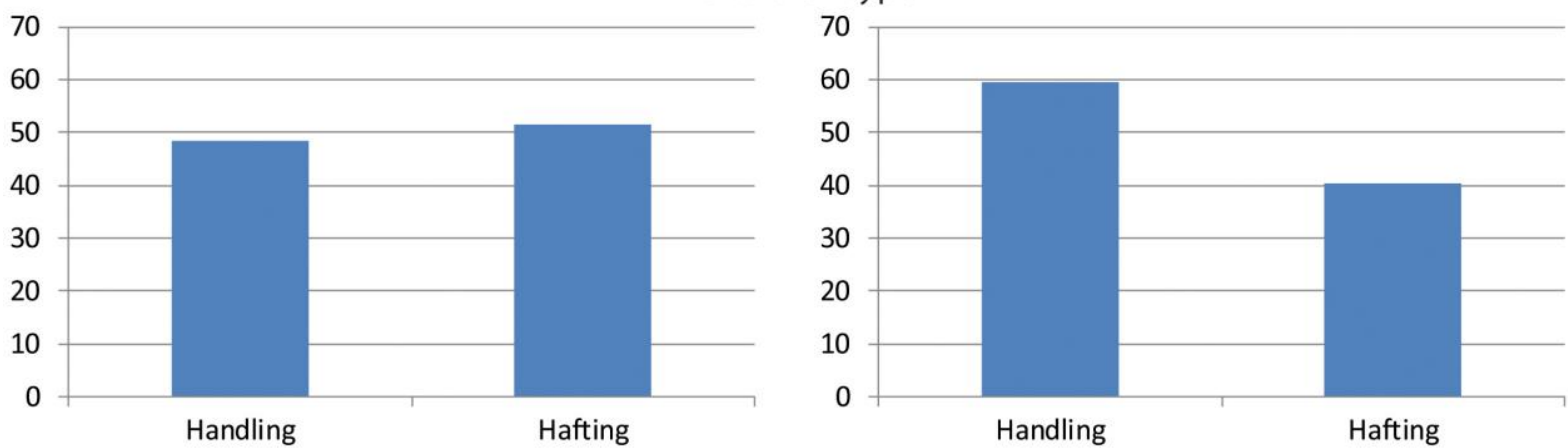

Figure 8. Distribution (percentages) of prehensile axis, prehension type and $\mathrm{TFU}_{\mathrm{p}}$ at Laguna Media 7 and Morro Blanco. 
Table 5. Frequencies and normalized residuals for the Prehensile TFU from Laguna Media 7 and Morro Blanco $\mathrm{x}^{2}$ and Monte Carlo results.

\begin{tabular}{|c|c|c|c|c|}
\hline \multirow[b]{2}{*}{ TFUp } & \multicolumn{2}{|c|}{$\begin{array}{l}\text { Frequency } \\
\end{array}$} & \multicolumn{2}{|c|}{ Residuals } \\
\hline & Laguna Media 7 & Morro Blanco & Laguna Media 7 & Morro Blanco \\
\hline Sinuous edge & 11 & 5 & -1.3478 & 1.3478 \\
\hline Back (knapping) & 17 & 3 & 1.5652 & -1.5652 \\
\hline Back (shaping) & 8 & 0 & 1.8261 & -1.8261 \\
\hline Thinning & 33 & 2 & 5.9891 & -5.9891 \\
\hline Stem & 1 & 8 & -5.9457 & 5.9457 \\
\hline Notches & 1 & 3 & -2.087 & 2.087 \\
\hline Total & 71 & 21 & & \\
\hline \multicolumn{5}{|l|}{ Chi squared } \\
\hline Rows, columns: & 6,2 & & Degrees freedom: & 5 \\
\hline$x 2:$ & 38.002 & & p (no assoc.): & $3.77 \mathrm{E}-07$ \\
\hline Monte Carlo $\mathrm{p}$ : & 0.0001 & & & \\
\hline
\end{tabular}

\subsection{The shaping methods}

In general, in Laguna Media 7, an even percentage was observed between the instruments whose TFU were mainly obtained by shaping (50\%) after knapping. On the other hand, the blanks were only marginally retouched (50\%) (Figure 9). In Morro Blanco, it was observed that the TFU of most tools were obtained only by knapping and retouching methods (73\%) while the tools in which TFUs were made through shaping were lower (27\%).

\section{LAGUNA MEDIA 7}

\section{MORRO BLANCO}

Removal extension
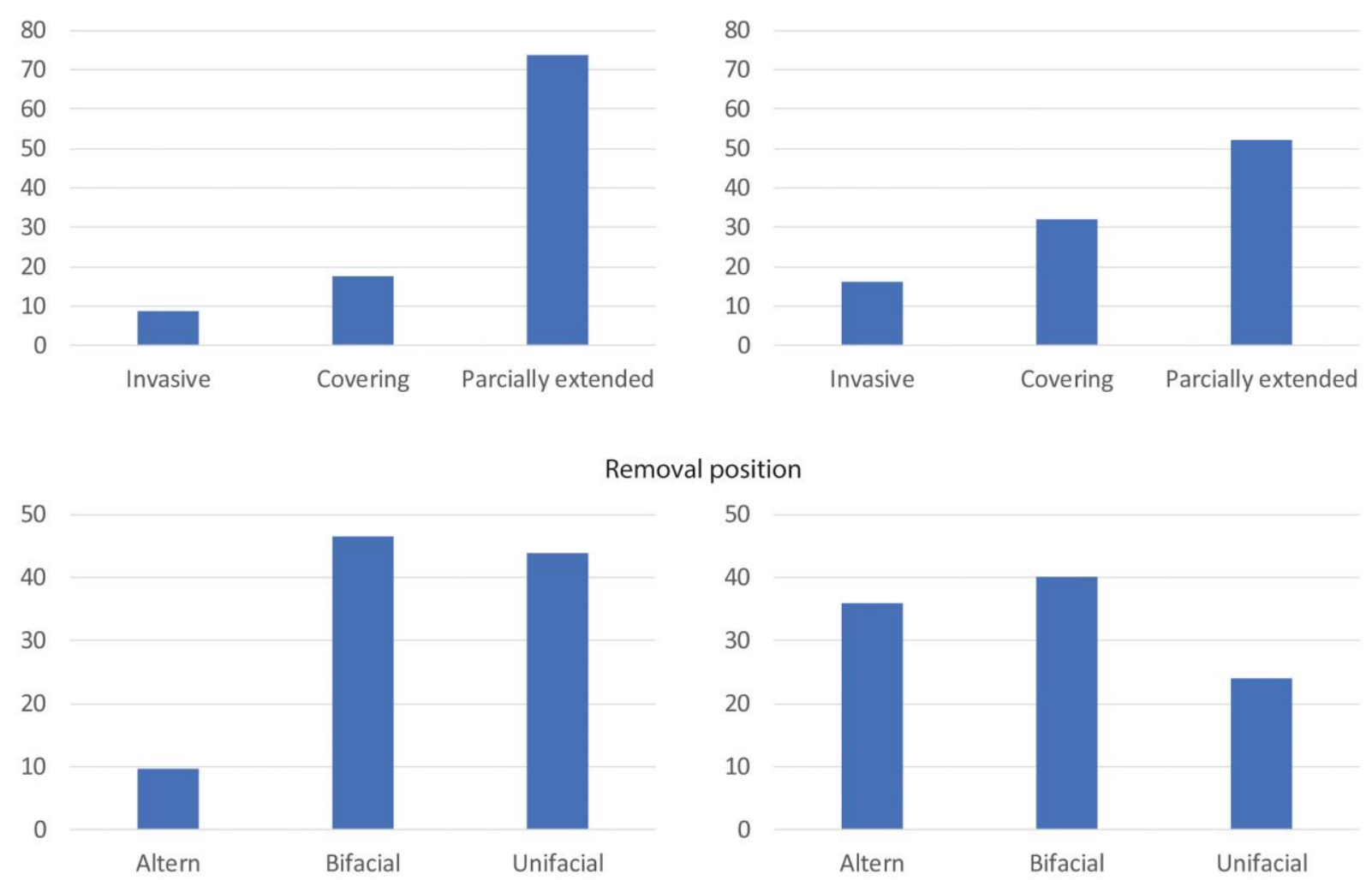

Figure 9. Distribution (percentages) of shaping methods on Laguna Media 7 and Morro Blanco. 
In both sites, the extent of the flaking over the instruments was mostly partially extended, and to a lesser extent, covering and invasive (Figure 9). However, in Laguna Media 7, the partial extension was more distinguished in relation to Morro Blanco. The alternate shaping was better represented in Morro Blanco, at the expense of unifacial shaping, which is better represented in Laguna Media 7 (Figure 9).

Some artefact classes deserve a more detailed description of their manufacturing sequence. In the case of the Saladillo technical tradition, the bulb was thinned and confection usually provided a lanceolate-shaped morphology and a flat-convex section (Figure 5: 1 to 6). According to each case, the confection involved more or less extended flaking on the dorsal side and a final bifacial or unifacial retouching. This variability was possibly the product of the different characteristics of the initial (unmodified) blades, and with the aim of obtaining a flat-convex section. However, the cultural weight (that is to say the last degrees of the events) of some aspects, such as the bulb thinning, was possible, since in some cases, as mentioned in Susques, it did not significantly diminish the proximal part of the piece, nor did the perimeter retouching rectify the curvature of the profile (Hoguin 2014a).

The bifacial lanceolate projectile points were present in both sites and were present during the Middle and Late Holocene at an important geographic scale (Aschero et al. 2011; Hoguin 2014b; Lavallée et al. 1995; 1997; Núñez et al. 2005; 2006; de Souza et al. 2010). These presented a variability of methods as shaping at least in two sequences with direct percussion and pressure (Hoguin 2014a). In some cases, the blanks seemed to be obtained to avoid an invasive confection (Figure 6: 11).

The test did not reject the null hypothesis regarding the shaping extension $\left(x^{2}, p>0.05\right)$ (Table 6). According to the normalized residuals, the category that would most mark differences were the partially extended flaking (Table 6). On the contrary, regarding the flake position, the results of the $\mathrm{x}^{2}$ were significant (Table 7), therefore rejecting the null hypothesis $\left(x^{2}, p=0.005\right)$. The normalized residuals suggest that alternate and, to a lesser extent, the unifacial shaping contributed substantially to the difference between the two sites, being the alternate less frequent than what would be expected by hazard in Laguna Media 7, where unifacial is more frequent (unlike Morro Blanco) (Table 7).

Table 6. Frequencies and normalized residuals for the shaping extension in the tools from Laguna Media 7 and Morro Blanco $-\mathrm{x}^{2}$ and Monte Carlo results.

\begin{tabular}{|c|c|c|c|c|}
\hline \multirow[b]{2}{*}{ Shaping Extension } & \multicolumn{2}{|c|}{ Frequency } & \multicolumn{2}{|c|}{ Residuals } \\
\hline & Laguna Media 7 & Morro Blanco & Laguna Media 7 & Morro Blanco \\
\hline Invasive & 10 & 4 & -1.482 & 1.482 \\
\hline Complete & 20 & 8 & -2.964 & 2.964 \\
\hline Partially extended & 84 & 13 & 4.446 & -4.446 \\
\hline Total & 114 & 25 & & \\
\hline \multicolumn{5}{|l|}{ Chi squared } \\
\hline Rows, columns: & \multicolumn{2}{|c|}{3,2} & Degrees freedom: & 2 \\
\hline $\mathrm{x} 2:$ & \multicolumn{2}{|c|}{4.5722} & $\mathrm{p}$ (no association): & 0.10166 \\
\hline Monte Carlo $\mathrm{p}$ : & \multicolumn{4}{|c|}{0.1009} \\
\hline
\end{tabular}

\subsection{The knapping methods}

Four principal core classes were identified at the sites: discoidal (and centripetal), SASP (system alternating surface and platform), blade and others (unidirectional and multidirectional type $\mathrm{C}$ and D). In both sites, a certain diversity was observed and quartzite is the dominant rock in cores in both sites (80\% in LM7 and $73 \%$ in AMB). The centripetal method usually involved a single extraction surface, while the discoidal method alternated 
two sides and produced a greater number of blanks (Figure 10). The blanks showed centripetal removals, dihedral or faceted platforms in the advanced phases, and in turn an overshot and flow side back (Figures 10 and 11). Let us make that clear: this kind of back is a facet that results from the percussion in a platform near the intersection of two removal surfaces following a sharp angle. The SASP method alternated platform and flaking surfaces, thus producing flakes with dihedral platforms from the second sequence onwards. In its most advanced phase, it could have produced a core flank flake with its typical back (Figure 10). Thus, this back is the remnant of the intersected neighbour surface and is more linked with the ventral than the dorsal face. Two methods of blade knapping, one unidirectional and the other bidirectional (Figure 12), were recognized here. They produced blades, with a module length/width equal or greater to 2, which served as blanks for the Saladillo tradition tools, present exclusively in Laguna Media 7. In Morro Blanco, unidirectional C-type flakes allowed the production of blanks of a certain size as those used for the burins (Figure 7: 20, 22). A multidirectional type D obsidian core was also found and could have been used as the blanks for the pedunculated projectile tips observed (Figure 11).

Table 7. Frequencies and normalized residuals for the shaping position in the tools from Laguna Media 7 and Morro Blanco - $\mathrm{x}^{2}$ and Monte Carlo results.

\begin{tabular}{lcccc}
\hline & \multicolumn{2}{c}{ Frequency } & \multicolumn{2}{c}{ Residuals } \\
Shaping Position & Laguna Media 7 & Morro Blanco & Laguna Media 7 & Morro Blanco \\
\hline Unifacial & 50 & 6 & 4.0719 & -4.0719 \\
Altern & 11 & 9 & -5.4029 & 5.4029 \\
Bifacial & 53 & 10 & 1.3309 & -1.3309 \\
\hline Total & 114 & 25 & & \\
Chi squared & & & Degrees freedom: & 2 \\
\hline Rows, columns: & 3,2 & & p (no assoc.): & 0.0023666 \\
x2: & 12.093 & & & \\
\hline Monte Carlo p : & 0.0016 & &
\end{tabular}

Although the different products resulting from the centripetal methods (including discoidal knapping) were present in both sites, in Morro Blanco they had a greater importance (Figure 13). Likewise, the knapping products obtained by the SASP method and the cores in Morro Blanco had greater importance in relation to Laguna Media 7, even though there, the blanks of the tools were better represented (Figure 13). It is necessary to clarify that the blanks produced by the SASP and discoidal methods were not always clearly identifiable, and had a marked equifinality in relation to other methods. Finally, the most marked trend in the site was regarding the blade production. The different products obtained by blade knapping were better represented in Laguna Media 7 than in Morro Blanco (Figure 13). Also, the difference in type $\mathrm{C}$ knapping was clear between both sites, but it is necessary to clarify that these types of products had an important equifinality with the flakes produced by other knapping methods, particularly in the initial stages (Figure 13). This could have been related to a greater integration of these products in the initial stages of the tool kit, and to a higher production in Morro Blanco. 
DISCOIDAL CORES
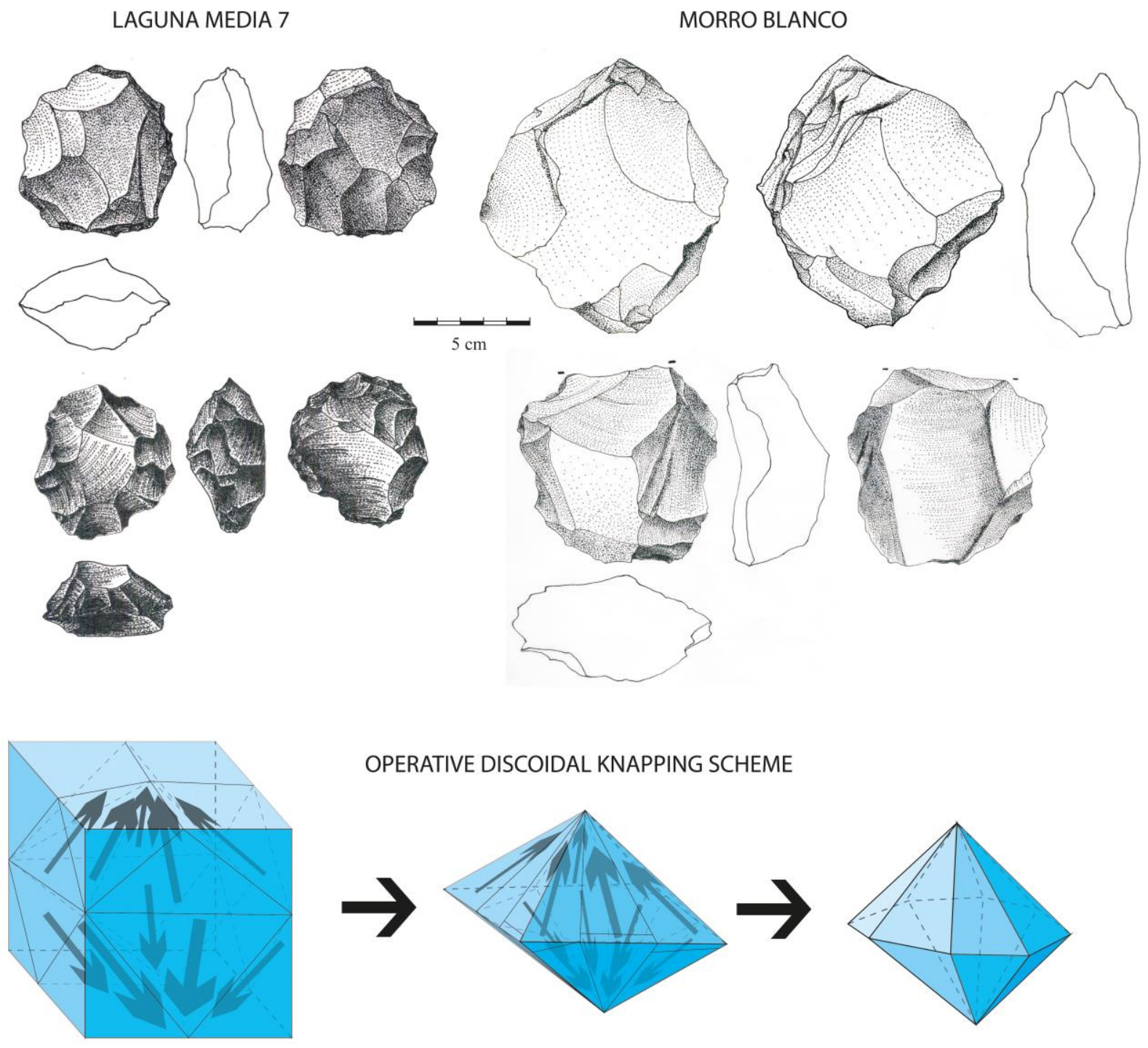

OPERATIVE DISCOIDAL KNAPPING SCHEME

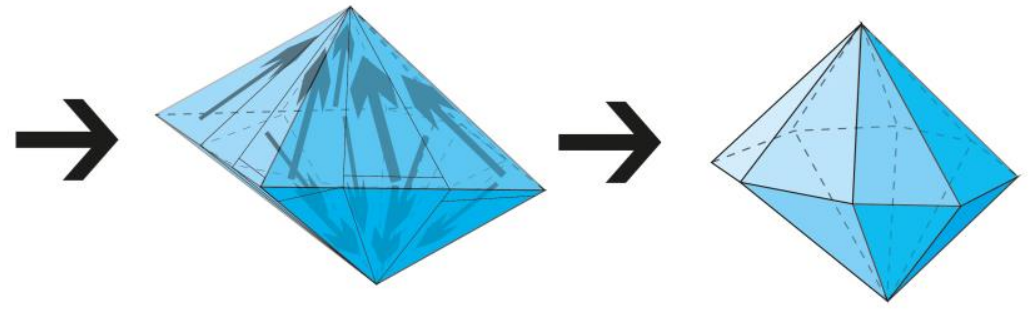

CENTRIPETAL BLANKS

LAGUNA MEDIA 7

MORRO BLANCO
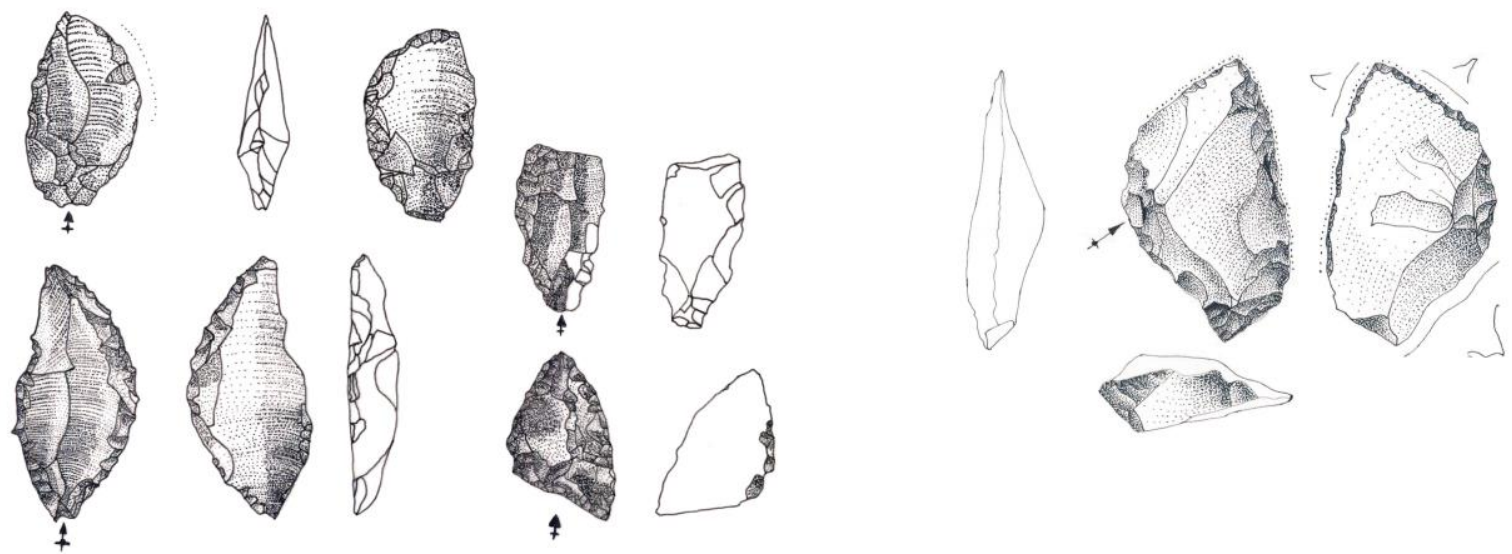

Figure 10. Discoidal operative schemes and centripetal by-products. 


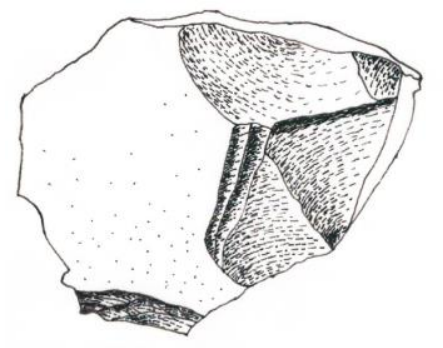

\section{MORRO BLANCO D TYPE CORES}
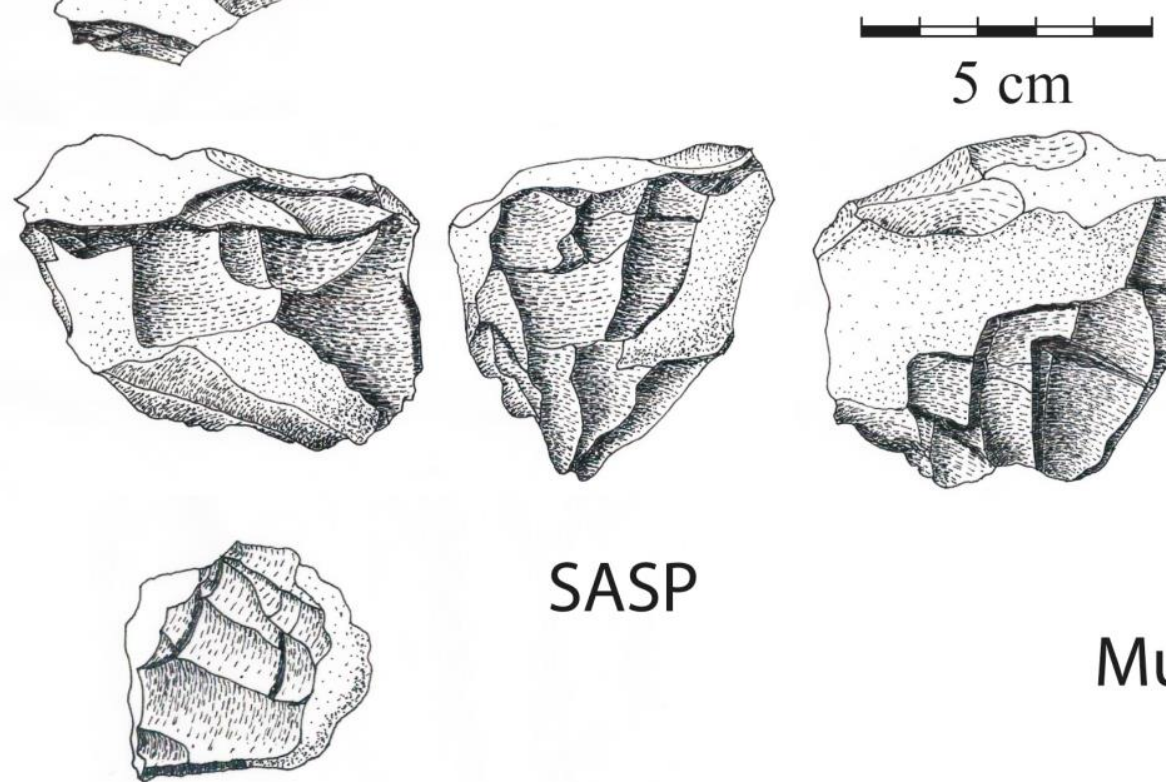

SASP

\section{Multidirectional}
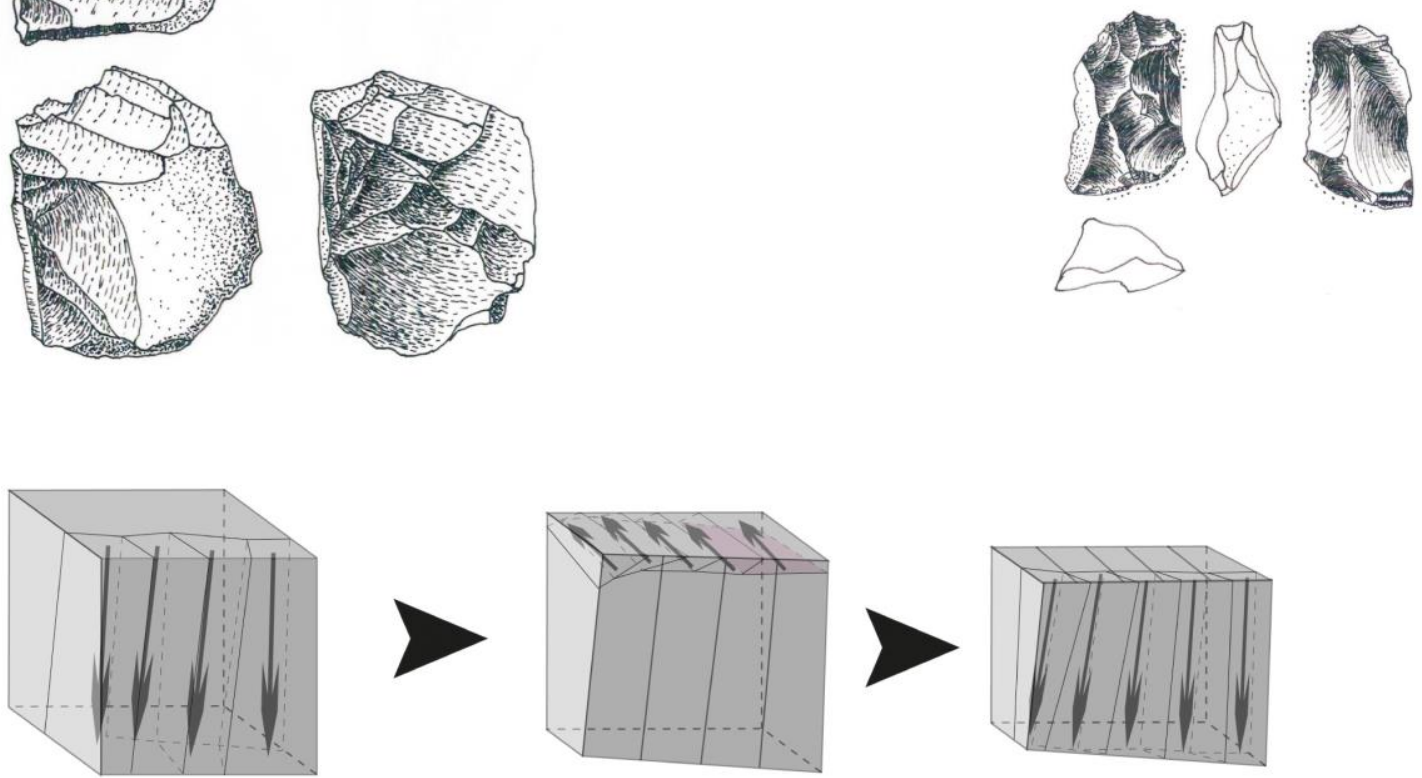

\section{OPERATIVE SASP KNAPPING SCHEME}
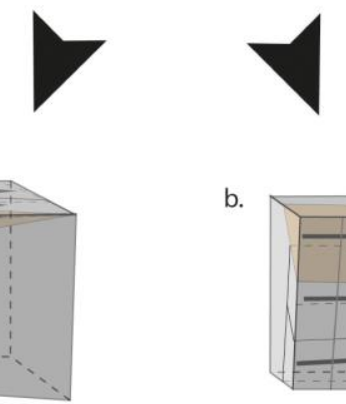

a.

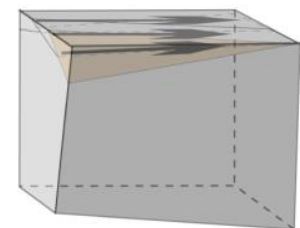

b.

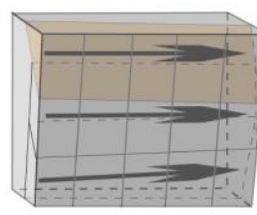

Figure 11. Other D type operative schemes and cores. Pink: Flow side back flake. Orange: Core flank flake. 
BLADE CORES (LAGUNA MEDIA 7)

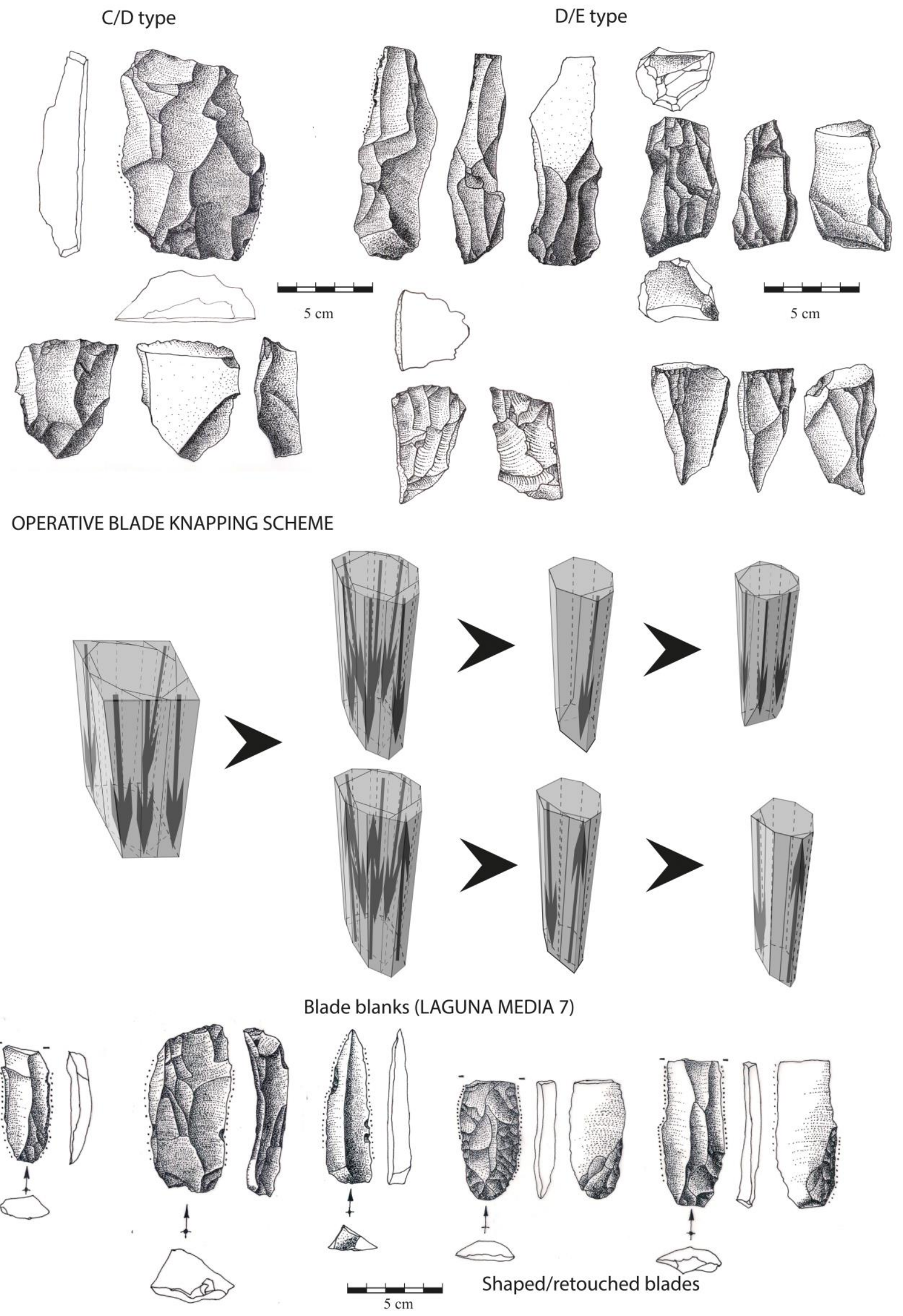

Figure 12. Blade operative schemes and by-products. 


\section{LAGUNA MEDIA 7}

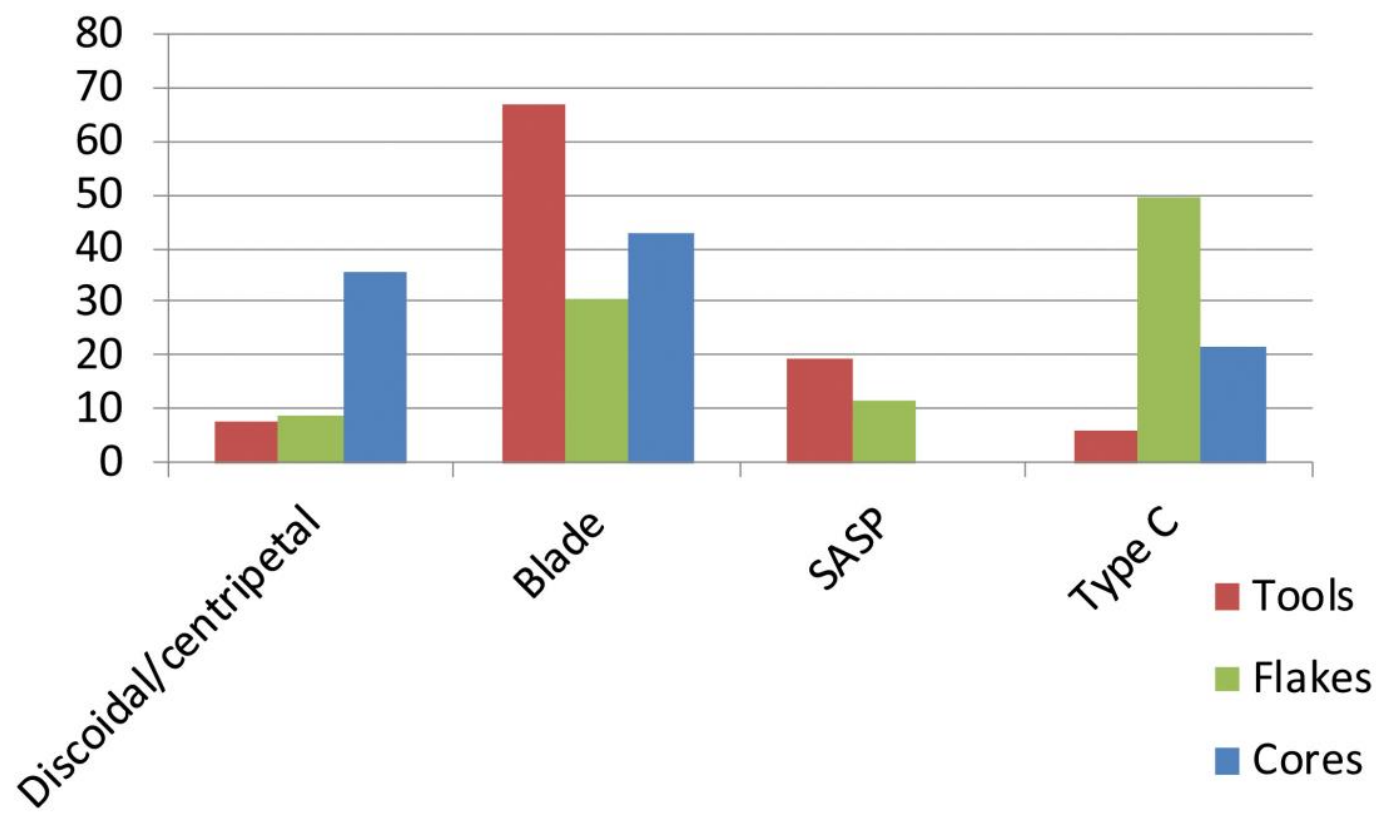

MORRO BLANCO

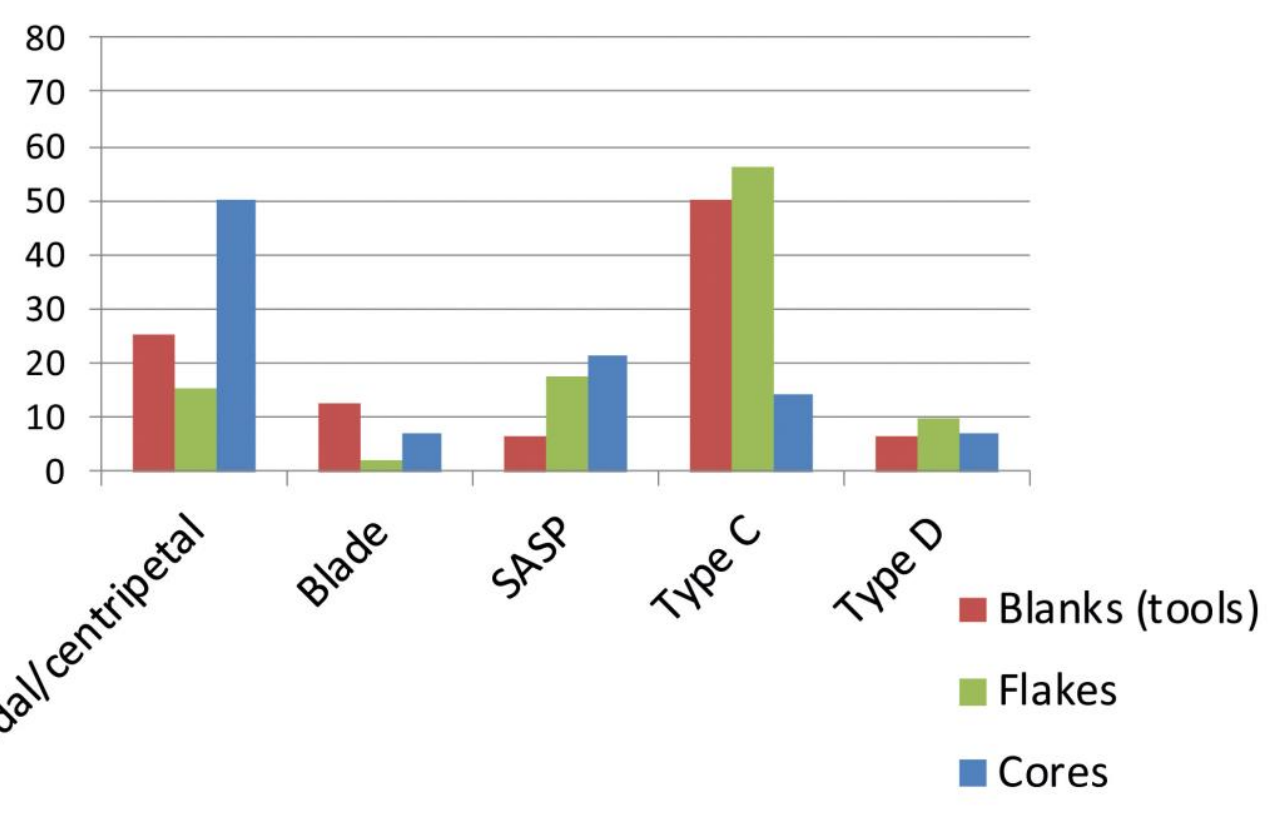

Figure 13. Distribution (percentages) of knapping by-products on Laguna Media 7 and Morro Blanco.

Finally, comparing the knapping methods from both sites, the $x^{2}$ result (Table 8) was particularly relevant, therefore rejecting the null hypothesis of association between both distributions $\left(\mathrm{x}^{2}, \mathrm{p}<0,001 \mathrm{p}=3,68 \mathrm{E}-26\right)$, which also supported the Monte Carlo approximation $(\mathrm{p}=0,0001)$. The normalized residuals confirmed the previous observations, as blade knapping represented a weight class in this analysis, being much more represented in Laguna Media 7 than in Morro Blanco. On the other hand, D type cores, were significant and relevant in Morro Blanco, while completely absent in Laguna Media 7. 
Table 8. Frequencies and normalized residuals for the knapping methods from Laguna Media 7 and Morro Blanco $-\mathrm{x}^{2}$ and Monte Carlo results.

\begin{tabular}{lcccc}
\hline & \multicolumn{2}{c}{ Frequency } & \multicolumn{2}{c}{ Residuals } \\
Knapping method & Laguna Media 7 & Morro Blanco & Laguna Media 7 & Morro Blanco \\
\hline Discoidal and centripetal & 37 & 39 & -3.1591 & 3.1591 \\
Blade & 161 & 7 & 9.859 & -9.859 \\
SASP & 52 & 36 & -1.2286 & 1.2286 \\
Type C & 149 & 114 & -3.6931 & 3.6931 \\
Type D & 0 & 20 & -6.1795 & 6.1795 \\
\hline Total & $\mathbf{3 9 9}$ & $\mathbf{2 1 6}$ & & \\
\hline Chi squared & 5, & \multicolumn{3}{|l}{} \\
\hline Rows, columns: & $5,25.44$ & Degrees freedom: & 4 \\
x2: & 0.0001 & p (no assoc.): & $3.68 \mathrm{E}-26$ \\
\hline Monte Carlo p : & \multicolumn{5}{|l}{} \\
\hline
\end{tabular}

\section{Discussion}

The period strictly addressed in this paper ranged from ca. 3400 to 2200 years BP. Theoretically, the chronology extended to ca. 5000 years BP thanks to the archaeological context of Antigal Laguna and Laguna Media 7, in particular due to the presence or the absence of certain technological features, such as ceramics, blades and stemmed projectile heads with barbed notches. At a regional scale, the Central-South Andes were the scene of several changes of various intensity in the different spheres of human occupations: social, cultural, economic and technological. One of the major changes of the societies during this period was regarding the domestication strategies of the camelids, and the consolidation of the herding strategies after them (López 2008; López \& Orsi 2017; López \& Restifo 2012; Olivera 2012; Yacobaccio 2001; among others). One can undoubtedly discuss about the fact that it was a social and economic context crossed by profound changes, possibly gradual and imperceptible on a smaller scale, but marked and notorious on an archaeological scale. The sedentarization process and the groups' growth accompanied these processes, concomitant with notable technological innovations (Muscio 2012; Muscio \& López 2017).

The palaeoenvironmental evidence showed a relatively wet phase at a regional level between ca. 4500 and $2500{ }^{14} \mathrm{C}$ years BP, although interrupted by dry and torrential events at the local level. In Barrancas, a relatively stable vega was detected, suitable for herding (Pirola et al. 2018). Also, a possible signal of pastoral activities in these vegas was detected from ca. $3600{ }^{14} \mathrm{C}$ years BP (Oxman 2015).

Particularly, in the basin of the Barrancas river, a marked chronological cut has been detected between ca. 3400 and $3200{ }^{14} \mathrm{C}$ years BP where ceramics (although in very low frequency in the beginning) and the bow and arrow hunting system appeared (reflected by the presence of pedunculated tips with fins), while certain technological features such as blade knapping disappeared. This change does not seem to be related to raw materials supplying the area, as local quartzite of medium quality is dominant in both sites, specifically related to blade technology and discoidal (and centripetal) knapping. Non-local obsidians with a very good knapping quality, and local quartz and opal outcrops presented as small nodules, mostly under ca. 12-20 cm (see also Yacobaccio et al. 2004 for obsidian sources), do not allow to produce blanks for different kind of tools discarded at both sites. On the contrary, local quartzite and non-local andesite blocks reach up to $40 \mathrm{~cm}$. Indeed, all the blade and discoidal (and centripetal) production is made on quartzite and andesite, in order to respect the size of blanks. Unlike this, the SASP and other Type D obsidian and quartz production consists of small blanks intended for projectile arrowheads in Morro Blanco. Particularly, we must 
highlight the changes occurring in all technical aspects: functional, prehensile and also production.

However, functional aspects may also be the result of different activities that take place at both sites. Burins used for art rock graving activities (Kohan 2018) and small projectile arrowheads used with bows made the difference in Morro Blanco. Only side-scrapers are common at both locations. In these cases, blanks are significantly different between the sites: blades on Laguna Media 7, and discoidal (and centripetal) or Type C flakes on Morro Blanco.

Despite these important changes, a certain continuity could be observed on a regional scale, as in the case of the presence of bifacial lanceolate arrowheads present before and after this chronological break (Aschero et al. 2011; Hoguin 2014a; Lavallée et al. 1995; 1997; Núñez et al. 2006; de Souza et al. 2010). The stem, in spite of being an almost exclusive technological hafting feature from Morro Blanco, could have been introduced progressively as it is shown in the following sketches of the lanceolate points, and some specimen of the triangular arrowheads (Figure 5B: 11, 12, 13, 15, 17, 19). This was also an observed phenomenon in other regions of the Puna (Hocsman 2010). In effect, the stem was not an exclusive hafting feature of the bow and arrow and was detected at the beginning of the Middle Holocene in a spear throwing system (Hoguin \& Yacobaccio 2012; Núñez et al. 2005; Restifo 2013a; 2013b). The technical sphere was not the only one involved here as funeral practices seem to also reflect some continuity and stabilization of hunter-gatherers in specific territories, as part of a "cult of ancestors" (Aschero 2007; Gonzalez Baroni et al. 2017). However, in the case of lithic technology, it is necessary to take necessary precautions with the continuity hypothesis as activities such as reactivation and the individual decisions of the knappers could introduce a certain variability that would correspond to the observed one.

Indeed, statistical data showed relevant changes beyond the differences linked to the function of each site (with burins and arrowheads more representative in Morro Blanco). Hafting modes showed clear differences with the stems in Morro Blanco and the bulb thinning of Saladillo tradition in Laguna Media 7. Shaping methods showed the weight of unifacial formatization as more typical at Laguna Media 7 and alternate methods were more common at Morro Blanco.

On the contrary, continuity was observed in the knapping methods from their qualitative study, except in the case of blade knapping which clearly decreased, if not entirely disappearing, between $c a .3400$ and 3200 years BP in the area, at least as a type D and E core. Only D type methods, other than blade and discoid production, showed some difference between the sites. Further, discoidal knapping was present in both sites and in similar proportions. No new shaping techniques or modalities were detected at the level of instrument confection over blanks, but the pressure technique should have taken a greater importance during the Late Holocene, given the more systematized use of obsidian at Morro Blanco and its better aptitude for smaller and thinner arrowhead, and the preparation of certain features such as the highlighted stemmed and barbed notches. It was also important to point out that unifacial shaping was more typical in Laguna Media 7, particularly associated with Saladillo type tools. As it was stated, the bulb thinning of these artefacts could have been related to a cultural aspect of the technical tradition and not only functional (Hoguin 2014a).

As for the backs $\mathrm{UTF}_{\mathrm{p}}$, those obtained by knapping were more common in Morro Blanco and the backs shaped after obtaining the blank were exclusively present in Laguna Media 7. Likewise, in a general way, the shaping was a more intense activity in Laguna Media 7 than in Morro Blanco. It is a logical phenomenon of technical evolution, since the changes tend to affect the instruments and the final operational chain stages first (that is to say the shaping of the blank), and only then the knapping methods, which are later arranged in a way to obtain the features sought in the blank without the need to further shaping (Boëda 2013). Obviously, it is not an intransigent rule, but an evolutionary trend. In this case, the ruptures caused would 
be related to deep cultural and social changes (Boëda 2013). In the case presented in this paper, we could observe clear technical change events, although some notable continuities were observed. That is to say: there were some marked changes but not a total disruption.

Functional, prehensile and production changes are linked to broad technical changes, as seen in a local and regional scale with the appearance of ceramics and architecture among others. In lithics, chaînes opératoires and related technical systems' changes may be mostly linked to subsistence strategies, and animal and vegetal raw material supply and processing. The beginning of herding in the region would make the difference between both sites, and could have possibly happened during this time in the Puna of Jujuy, identified by the presence of the taxa Lama glama (Yacobaccio 2001). In fact, it is the herding strategy which has greater impact in by-products supplying as milk and wool, among others (Ghesquière 2018). Butchering and other processing activities, and related technical systems might have been affected by domestication and then herding strategies. However, technical systems and subsistence economies may be a concomitant phenomenon, whose changes would be due to a root cause, as social and ecological structuration of populations. New activities, territories and social relationship networks during Late Holocene should have affected resources supplying, gestures and associated technical systems. Blades, for instance could have become obsolete in a context with differential supplying of allochthone resources, as chusquea lorentziana being used as shafts (Mondini et al. 2013; Pintar \& Rodriguez 2015). These seem have only been used to haft projectile arrowheads with peduncle with the introduction of the bow and arrow propulsion system, whereas butchering, collection and processing activities used manual prehension. Pre-existent Type E (integrated) production structures as discoid knapping could have substituted blade ones, offering the same degree of integration, but possibly better adapted to new requirements.

\section{Conclusions}

During the end of the Middle Holocene and the beginning of the Late Holocene, several ecological, social and economic changes affected the technical systems, which probably underwent modifications on a regional scale, from its techno-economic and economic aspects. On the other hand, in spite of notable discontinuities, it was observed that the operational chains remained unaltered at a local level. The main changes seem to have mainly affected both the hafting and prehensile methods, and also led to a more systematized supply of obsidian nodules. In this way, the adoption of the bow and arrow propulsion system, as well as the caravan traffic in the beginning of the Late Holocene (as a form of procurement of valuable resources such as obsidian and even knowledge) could have had an influence on technical systems. New knowledge, goods and people should have circulated in such contexts. The human group kept mainly flexible technical systems ( $C$ and $D$ ones), and the innovations previously mentioned could have arisen in the context of bigger exchange processes and steadier networks. The technical production systems were adapted to the new changes affecting the technical systems, through original solutions of the local knappers adapting their know-how.

\section{Acknowledgements}

Thanks to Hugo Yacobaccio and Eric Boëda for their academic support and advices. To Martin Alejo, Faustino Gutierrez, Cupertino Lamas, Teresa Flores and the municipality of Barrancas for their help and support during field work. This research was funded by the following projects: Mission Archéologique Française en Argentine (Ministère des Affaires Etrangères et du Développement International), CONICET PIP0569, UBACyT F230BA. Thank to Christine Hatté and the LSCE laboratory (Gif-sur-Yvette) for the AMS datations 
and the LATYR laboratory (La Plata) for radiocarbon datess. Thanks to Marcelo Cardillo for his help on statistical analysis, and to Kevin Lane for the revision and comments of this manuscript. We also want to thank the following peoples for their help during field and laboratory works: Patricia Solá, Brenda Oxman, Marcelo Morales, Malena Pirola, Julia Merler, Mercedes Rouan Sirolli and Sabrina Bustos. Finally, we want to thank the organizers of the ISKM congress in Argentina, Otis Crandell and guest editors of the Journal of Lithic Studies, and a special thanks to Claudine Karlin for her encouraging review.

\section{References}

Angiorama, C.I. \& Taboada, C. 2008, Metales andinos en la llanura santiagueña (Argentina). Revista Andina, 47: 117-150. (in Spanish) ("Andean metals in the Santiago del Estero plain (Argentina)")

Aschero, C. A. 2007, Íconos, huancas y complejidad en la Puna sur argentina. In: Procesos sociales prehispánicos en el sur andino: La vivienda, la comunidad y el territorio. Tomo II (Comp.) (Nielsen, A., Rivolta, M., Seldes, V., Vazquez, M. \& Mercolli, P., Eds.), Editorial Brujas, Córdoba: p. 259-290. (in Spanish) ("Icons, huancas and complexity in the southern Argentine Puna")

Aschero, C. \& Hocsman, S. 2011, Arqueología de las ocupaciones cazadoras-recolectoras de fines del Holoceno Medio de Antofagasta de la Sierra (Puna Meridional Argentina). Chungara, 43: 393-411. (in Spanish) ("Archeology of hunter-gatherer occupations at the end of the Middle Holocene of Antofagasta de la Sierra (Puna Meridional of Argentina)") doi:10.4067/S0717-73562011000300005

Aschero, C., Hocsman, S. \& Ratto, N. 2011, Las puntas de proyectil en mandorla de Inca Cueva 7. Estudios Atacameños, 41: 5-28. (in Spanish) ("The mandorla projectile points from Inca Cueva 7’) doi:10.4067/S0718-10432011000100002

Babot, P. 2011, Cazadores-Recolectores de los Andes Centro-Sur y Procesamiento Vegetal. Una Discusión desde la Puna Meridional Argentina (ca. 7.000-3.200 años A.P.). Chungara, 43(Número Especial 1): 413-432. (in Spanish) ("Hunters-Gatherers of the South-Central Andes and Vegetal Processing. A Discussion from the Southern Puna of Argentina (ca. 7,000-3,200 years A.P.)") doi:10.4067/S0717-73562011000300006

Boëda, E. 2013, Techno-logique \& Technologie: Une paléo-histoire des objets lithiques tranchants, (1st ed.), @rcheo-editions, Paris, 259 p. (in French) (“Techno-logic \& Technology: A palaeo-history of sharp lithic objects")

Cartagena, I., Núñez, L. \& Grosjean, M. 2007, Camelid domestication on the western slope of the Puna de Atacama, northern Chile. Anthropozoologica, 42(2): 155-173.

Delfino, D., Espiro, V. \& Díaz, A. 2007, Excentricidad de las periferias: La región puneña de Laguna Blanca y las relaciones económicas con los valles mesotermales durante el primer milenio. In: Producción y circulación prehispánicas de bienes en el sur andino (Nielsen, A., Rivolta, M., Seldes, V., Vazquez, M. \& Mercolli, P., Eds.), Editorial Brujas, Córdoba: p. 167-190. (in Spanish) ("Eccentricity of the peripheries: The Puna region of Laguna Blanca and economic relations with the mesothermal valleys during the first millennium")

Escola, P. 2000, Tecnología lítica y sociedades agro-pastoriles tempranas. Doctoral thesis at the Facultad de Filosofía y Letras, Universidad de Buenos Aires, Buenos Aires, 326 p. (in Spanish) ("Lithic technology and early agro-pastoral societies") 
Escola, P. 2002, Caza y pastoralismo: Un reaseguro para la subsistencia. Relaciones de la Sociedad Argentina de Antropología, 27: 233-246. (in Spanish) ("Hunting and pastoralism: A reinsurance for subsistence")

Fernández Distel, A. 1998, Arqueología del Formativo en la Puna Jujeña 1800 ac. al 650 dc., CAEA, Buenos Aires, 150 p. (in Spanish) ("Formative archaeology in the Puna Jujeña from 1800 B.C. to 650 A.D.")

Geneste, J.-M. 2010, Systèmes techniques de production lithique. Techniques \& Culture, 5455(2): 419-449. (in French) (“Technical systems of lithic production”)

González, R. 2004, La arqueología del noroeste argentino y las culturas formativas de la cuenca del Titicaca. Relaciones de la Sociedad Argentina de Antropología, 29: 7-38. (in Spanish) (The archaeology of the Argentine northwest and the formative cultures of the Titicaca basin")

Gonzalez Baroni, L. G., Hocsman, S. \& Aschero, C. A. 2017, Prácticas mortuorias de cazadores-recolectores tardíos de los desiertos de altura del Noroeste argentino: El fardo funerario de Quebrada Seca 3. Revista Argentina de Antropología Biológica, 19(1): 724. (in Spanish) (Mortuary practices of late hunter-gatherers of the high deserts of the Argentine northwest: The funerary bundle of Quebrada Seca 3")

Hocsman, S. 2010, Cambios en las puntas de proyectil durante la transición de cazadoresrecolectores a sociedades agro-pastoriles en Antofagasta de la Sierra (Puna argentina). Arqueología, 16: 59-86. (in Spanish) ("Changes in the projectile points during the hunter-gatherers transition towards agro-pastoral societies in Antofagasta de la Sierra (Argentinean Puna)")

Hoguin, R. 2014a, La tecnología de hojas durante el Holoceno medio en la Puna oriental de Atacama: El caso de Susques (Provincia de Jujuy, Argentina). In: Poblamiento de América del sur: La contribución de la tecnología lítica (Farias, M., Lourdeau, A. \& Boëda, E., Eds.), @ archéo-éditions, Paris, p. 221-253. (in Spanish) ("The blade technology during the middle Holocene in the eastern Puna of Atacama: The case of Susques (Province of Jujuy, Argentina)")

Hoguin, R. 2014b, Secuencia cronológica y Tecnología lítica en la Puna Seca de los Andes Centro-Sur para el Holoceno temprano y medio a través el ejemplo de Susques. Relaciones de la Sociedad de Antropología Argentina, 39: 333-364. (in Spanish) ("Chronological sequence and lithic technology in the Dry Puna of the center-south Andes for the early and middle Holocene through the example of Susques")

Hoguin, R. \& Yacobaccio, H. D. 2012, Análisis lítico de ocupaciones del Holoceno medio de Hornillos 2 (Jujuy, Argentina): Discutiendo la tecnología y distribución de las puntas de proyectil "San Martín". Chungara, 44(1): 81-95. (in Spanish) ("Lithic analysis of the Holocene occupation of Hornillos 2 (Jujuy, Argentina)") doi:10.4067/S071773562012000100007

Inizan, M.-L., Reduron, M., Roch, H. \& Tixier, J. 1995, Technologie de la pierre taillée. CREP, Paris, 199 p. (in French) ("Technology of the knapped stone”)

Kohan, P. 2018, Tecnología lítica y petroglifos en Barrancas, Jujuy. BA thesis at the Facultad de Filosofía y Letras, Universidad de Buenos Aires, Buenos Aires, 166 p. (in Spanish) ("Lithic technology and petroglyphs in Barrancas, Jujuy") 
Korstanje, A. 2007, Territorios Campesinos: Producción, Circulación y Consumo en los Valles Altos. In: Producción y circulación prehispánicas de bienes en el sur andino (Nielsen, A., Rivolta, M., Seldes, V., Vazquez, M. \& Mercolli, P., Eds.), Editorial Brujas, Córdoba: p. 191-223. (in Spanish) ("Peasant Territories: Production, Circulation and Consumption in the High Valleys")

Lavallée, D., Julien, M., Wheeler, J. \& Karlin, C. 1995, Telarmachay: Chasseurs et Pasteurs Préhistoriques des Andes - 1. Editions Recherches sur les Civilisations, Association pour la Diffusion de la Pensée Française (ADPF), Paris, 461 p. (in French) ("Telarmarchay: Prehistoric hunters and herders of the Andes")

Lavallée, D., Julien, M., Karlin, C., García, L. C., Pozzi-Escot, D. \& Fontugne, M. 1997, Entre Desierto y Quebrada. Primeros resultados de las excavaciones realizadas en el abrigo de Tomayoc (Puna de Jujuy, Argentina). Bulletin Français des Études Andines, 26(2): 141-175. (in Spanish) ("Between the desert and the canyon. First results of the excavations made in the Tomayoc shelter (Puna of Jujuy, Argentina)")

Lemonnier, P. 1986, The study of material culture today: Towards an anthropology of technical systems. Journal of Anthropological Archaeology, 5: 147-186. doi:10.1016/0278-4165(86)90012-7

Leroi-Gourhan, A. 1971, Evolution et techniques. Milieu et Techniques. Albin Michel, Paris, 475 p. (in French) ("Evolution and techniques. The man and the techniques")

López, G. E. 2008, Arqueología de Cazadores y Pastores en Tierras Altas: Ocupaciones humanas a lo largo del Holoceno en Pastos Grandes, Puna de Salta, Argentina. BAR International Series, Oxford, 280 p. (in Spanish) (“Archeology of Hunters and Herders in the Highlands: Human occupation along the Holocene in Pastos Grandes, Puna of Salta, Argentina")

López, G. \& Orsi, J.P. 2017, El sitio Abrigo Pozo Cavado, Puna de Salta. Nuevo aporte arqueológico y cronológico para el estudio de procesos de cambio hacia finales del Holoceno medio (ca. 5600-4600 a-os AP). Revista del Museo de Antropología, 10(1): 43-48. (in Spanish) ("The Abrigo Pozo Cavado site, Puna of Salta. New archaeological and chronological contribution for the study of change processes towards the end of the middle Holocene (ca. 5600-4600 years BP)")

López, G. \& Restifo, F. 2012, Middle Holocene intensification and domestication of camelids in north Argentina, as tracked by zooarchaeology and lithics. Antiquity, 86: 1041-1054. doi:10.1017/S0003598X00048237

Loyola, R., De Souza, P. \& Santander, B. D. 2016, El desbaste de hojas durante la transición Arcaico Tardío-Formativo Temprano en la Quebrada de Tulán, Región de Antofagasta. In: Actas del XIX Congreso Nacional de Arqueología Argentina (Facultad de Ciencias naturales \& Instituto Miguel Lillo, San Miguel de Tucumán Ed.), Serie Monográfica y Didáctica Volumen 54,: p. 1460-1466. (in Spanish) ("Blade knapping during the Late Archaic-Early Formative in the Quebrada of Tulan, región of Antofagasta")

Mauss, M. 1950, Sociologie et Anthropologie, Presses Universitaires de France (PUF), Quadrige, Paris: 540p. (in French) ("Sociology and Anthropology")

Mercuri, C. 2014, Conjuntos líticos formativos del sitio Alero Cuevas (Salta, Argentina): Puesto de caza de pastores de altura. Intersecciones en Antropología, 15(1): 251-264. (in Spanish) ("Formative lithic assemblages from the Alero Cuevas site (Salta, Argentina)") 
Mondini, M., Martínez, J. G., Pintar, E. \& Reigadas, M. C. 2013. Middle Holocene foraging, mobility and landscape use in the southern Argentinean Puna: Hunter-gatherers from Antofagasta de la Sierra, Catamarca, Argentina. Quaternary International, 307: 66-73. doi:10.1016/j.quaint.2013.05.015

Morales, M.R., Tchilinguirian, P., Pirola, M. \& Bustos, S. 2014, New Holocene paleoenvironmental records from the Dry Puna, northwestern Argentina. In: Book of Abstracts of the 4th Southern Deserts Conference (Barberena, R. \& Marsh, E., Eds.), Universidad Nacional de Cuyo, Mendoza: p. 81.

Muscio, H. J. 2011, Ocupaciones humanas a cielo abierto de finales del Holoceno medio y comienzos del Holoceno tardío en el Valle de San Antonio de los Cobres, Puna de Salta. Comechingonia, 15: 71-90. (in Spanish) ("Human open-air occupations from the late middle Holocene and early late Holocene in the Valley of San Antonio de los Cobres, Puna of Salta")

Muscio, H. J. 2012, Modelling demographic dynamics and cultural evolution: The case of the early and mid-Holocene archaeology in the highlands of South America. Quaternary International, 256: 19-26. doi:10.1016/j.quaint.2011.10.021

Muscio, H. \& López, G. 2017, Radiocarbon dates and anthropogenic signal in the SouthCentral Andes (12,500-600 cal. years BP). Journal of Archaeological Science, 65: 93102. doi:10.1016/j.jas.2015.11.007

Núñez, L., Cartajena, F. I., Carrasco, G. C., de Souza, H. P. \& Grosjean, M. 2006, Emergencia de comunidades pastoralistas formativas en el sureste de la Puna de Atacama. Estudios Atacameños, 31: 93-117. (in Spanish) (“Appearance of formative pastoral communities in the southeast of the Puna of Atacama")

Núñez, L., Grosjean, M. \& Cartagena, I. 2005, Ocupaciones Humanas y Paleoambientes en la Puna de Atacama. Instituto de Investigaciones Arqueológicas y Museo, Universidad Católica del Norte - Taraxacum, San Pedro de Atacama, 480 p. (in Spanish) ("Human occupations and palaeoenvironments in the Puna of Atacama")

Núñez, L., Cartagena, I. \& Grosjean, M. 2013, Archaeological silence and ecorefuges: Arid events in the Puna of Atacama during the Middle Holocene. Quaternary International, 307: 5-13. doi:10.1016/j.quaint.2013.04.028

Olivera, D. 2012, El Formativo en los Andes del Sur: La incorporación de la opción productiva. In: Interculturalidad y Ciencias. Experiencias desde América Latina (de Haro, M. T., Rocchietti, A. M., Runcio, M. A., Hernández de Lara, O. \& Fernández, M. V., Eds.), Centro de Investigaciones Precolombinas, Buenos Aires: p. 15-49. (in Spanish) ("The Formative in the southern Andes: The incorporation of the productive option")

Oxman, B. 2015, Paleoambiente y sociedad durante el Holoceno en la Puna de Jujuy: Un abordaje arqueopalinológico. Ph.D. thesis at the Universidad de Buenos Aires, Facultad de Filosofía y Letras, Buenos Aires, 258 p. (in Spanish) ("Palaeoenvironment and society during the Holocene in the Puna of Jujuy: An archaeopalinological approach")

Pelegrin, J. 1995, Technologie lithique: Le Châtelperronien de Roc-de-Combe (Lot) et de La Côte (Dordogne). Cahiers du Quaternaire no. 20, CNRS (Centre National de Recherches Scientifiques) Edition, Paris, 297 p. (in French) ("Lithic technology: The Chatelperronian from Roc-de-Combre (Lot) and La Côte (Dordogne)") 
Pintar, E. \& Rodríguez, M. F. 2015. Understanding foraging radius and mobility in a high desert. Journal of Archaeological Science, 59: 142-158. doi:10.1016/j.jas.2015.04.013

Pirola, M., Bustos, S., Morales, M. R., Orgeira, M. J., Oxman, B. I., Tchilinguirian, P. \& Vázquez, C. 2018, The mid to late Holocene transition in Barrancas, Jujuy, Argentina: Regional climate change, local environments and archaeological implications. Journal of Archaeological Sciences: Reports, 18: 722-738. doi:10.1016/j.jasrep.2017.06.019

Restifo, F. 2013a, Tecnología de caza durante el Holoceno temprano y medio en la Puna de la Provincia de Salta (República Argentina): Patrones de variación y procesos de cambio. Comechingonia, 17: 59-84. (in Spanish) ("Hunting technology during the early and middle Holocene in the Puna of the Province of Salta (Argentine Republic): variation patterns and change processes")

Restifo, F. 2013b, Herramientas teórico-metodológicas para el análisis del cambio en la tecnología lítica: Aportes desde una perspectiva evolutiva. Arqueología, 19 Dossier: 125-149. (in Spanish) ("Theoretical-methodological tools for the analysis of change in lithic technology: Contributions from an evolutionary perspective")

Restifo, F. 2015, Tecnología de hojas líticas en tierras altas andinas: Perspectivas desde la Puna de la Provincia de Salta (Argentina). Estudios Atacameños, 51: 33-51. (in Spanish) ("Lithic blade technology in the Andean highlands: Perspectives from the Puna of Salta (Argentina)")

Roux, V. 2010, Technological Innovations and Developmental Trajectories: Social Factors as Evolutionary Forces. In: Innovation in Cultural Systems: Contributions from Evolutionary Anthropology (O'Brien, M. J. \& Shennan, S. J., Eds.), MIT Press, Massachusetts: p. 217-233.

de Souza, P., Cartajena, I., Nuñez, L. \& Carrasco, C. 2010, Cazadores-recolectores del Arcaico Tardío y desarrollo de complejidad social en la Puna de Atacama: Las evidencias del sitio Tulan-52 (norte árido de Chile). Werken, 13: 91-118. (in Spanish) ("Hunter-gatherers of the Late Archaic and the development of social complexity in the Puna de Atacama: The evidences of the site Tulan-52 (arid north of Chile)")

Tchilinguirian, P., Morales, M.R., Oxman, B., Lupo, L.C., Olivera, D.E. \& Yacobaccio, H.D. 2014, Early to middle Holocene transition in the Pastos Chicos record, dry Puna of Argentina. Quaternary International, 330: 171-182. doi:10.1016/j.quaint.2012.03.006

Yacobaccio, H. D. 2001, Cazadores recolectores complejos y domesticación de camélidos. In: El uso de los camélidos a través el tiempo (Mengoni, G., Olivera, D. \& Yacobaccio, H. D., Eds.), Edición del Tridente, Buenos Aires: p. 261-282. (in Spanish) (“Complex hunter-gatherers and domestication of camelids")

Yacobaccio, H. D. 2012, Intercambio y caravanas de llamas en el sur andino (3000-1000 AP). Comechingonia, 16: 31-51. (in Spanish) ("Exchange and caravans of llamas in the Andean south (3000-1000 AP)")

Yacobaccio, H. D., Escola, P. S., Pereyra, F. X., Lazzari, M. \& Glascock, M. D. 2004, Quest for ancient routes: Obsidian sourcing research in northwestern Argentina. Journal of Archaeological Science, 31: 193-204. doi:10.1016/j.jas.2003.08.001

Yacobaccio, H. D., Madero, C. M., Malmierca, M. P. \& Reigadas, M. C. 1998, Caza, domesticación y pastoreo de camélidos en la Puna Argentina. Relaciones de la Sociedad Argentina de Antropología, 22-23(1997-1998): 389-418. (in Spanish) ("Hunting, domestication and herding of camelids in the Argentinean Puna") 
Yacobaccio, H., Catá, P., Morales, M., Solá, P., Alonso, S., Rosenbuch, M., Vázquez, C., Samec, C., Oxman, B. \& Cáceres, M. 2011, El uso de cuevas por pastores andinos: El caso de cueva Quispe (Susques, Puna de Jujuy). In: Arqueología de la Puna argentina: Perspectivas actuales en el estudio de la diversidad y el cambio cultural (López, G. \& Muscio, H., Eds.), BAR International Series, Oxford: p. 33-47. (in Spanish) ("The use of caves by Andean herders: The case of Quispe cave (Susques, Puna of Jujuy)")

Yacobaccio, H. D., Hoguin, R., Solá, P., Rouan Sirolli, M., Kohan, P., Oxman, B., Morales, M., Pirola, M. \& Merler, J. (2018), Ocupaciones tempranas (ca.3200-2200 años AP) en el Alero del Morro Blanco (Barrancas, Pcia. de Jujuy, Agentina): Resultados preliminares. manuscript submitted for review and publication. 26p. (in Spanish) ("Early settlement (ca. 3200-2200 years BP) in Morro Blanco rock shelter (Barrancas, Province of Jujuy, Argentina): Preliminary results")

Yacobaccio, H. D., Hoguin, R. \& Glascock, M. 2017, Obsidian supply and circulation in Puna of Jujuy province. In: 11th International Symposium on Knappable Materials. "From Toolstone to Stone Tools", Book of Abstracts, IMHICIHU, CONICET (Instituto Multidisciplinario de Historia y Ciencias Humanas, Concejo Nacional en Ciencias y Técnicas), Buenos Aires: p. 93. 